This is a post-peer-review, pre-copyedit version of an article published in Evolutionary Ecology. The final authenticated version is ava lable online at: https://doi.org/10.1007/s10682-p19-10004-5

\title{
1 A test of the evolution of increased competitive ability in two invaded regions.
}

2 Michael C. Rotter ${ }^{1}$, Mario Vallejo-Marin ${ }^{2}$, and Liza M. Holeski ${ }^{1}$

3 1. Department of Biological Sciences, Northern Arizona University, PO Box: 5640, Flagstaff AZ

$4 \quad 86011-5640$

5 2. Biological and Environmental Sciences, Faculty of Natural Sciences, University of Stirling,

6 Stirling FK9 4LA, UK

7 Correspondence. Michael C. Rotter, Department of Biological Sciences, Northern Arizona

8 University, PO Box: 5640, Flagstaff AZ 86011-5640. Email. mcr268@ nau.edu

$9 \quad$ Running Title: Evolution of increased competitive ability in two invaded regions

10 Keywords: Evolution of increased competitive ability, Mimulus guttatus, invasion ecology,

11 herbivores, evolutionary ecology.

12 Word Count: 6972

13 Figures and Tables: 8 figures and 3 tables

14 Items for online supplemental: Table of populations used in the study, Correlation Matrixes

15 between resistance traits and fitness/ competitive ability traits, Eastern North American plant

16 supplemental.

17

18 


\section{Abstract}

22 Non-native plant species invasions can have significant ecological and economic impacts.

23 Finding patterns that predict and explain the success of non-native species has thus been an

24 important focus in invasion ecology. The evolution of increased competitive ability (EICA)

25 hypothesis has been a frequently used framework to understand invasion success. Evolution of

26 increased competitive ability predicts that (1) Non-native populations will escape from

27 coevolved specialist herbivores that were present within the native range and this release from

28 specialist herbivores should result in relaxed selection pressure on specialist-related defense

29 traits, (2) There will be a trade-off between allocation of resources for resistance against

30 specialist herbivores and allocation to traits related to competitive ability, and (3) This shift will

31 allow more allocation to competitive ability traits. We tested the predictions of EICA in the

32 model plant Mimulus guttatus, a native of western North America (WNA). We compared how

33 well the predictions of EICA fit patterns in two non-native regions, the United Kingdom (UK),

34 an older more successful invasion, and eastern North America (ENA), a younger less successful

35 invasion. We completed extensive herbivore surveys and grew plants derived from multiple

36 populations in each region in a common greenhouse environment to test adherence to the

37 predictions of EICA. We found evidence of specialist herbivore escape in the UK, but not the

38 ENA plants. Compared to native plants the UK plants had lower levels of resistance traits, were

39 taller, and produced larger and more flowers, while the ENA plants had mostly equivalent traits

40 to the WNA plants. Plants from the UK conformed to the predictions of EICA more closely than

41 those from ENA. The UK invasion is an older, more successful invasion, suggesting that support

42 for EICA predictions may be highest in more successful invasions. 
45 The translocation of non-native species into areas outside of their native range provides unique 46 opportunities for the study of evolution (Cox 2004), including how selection pressures from

47 herbivores can shape plant defense evolution (Callaway and Maron 2006). Comparisons between

48 divergent biotic and abiotic factors in the native and non-native habitats can aid understanding of

49 how these variables shape evolution in non-native plants (Whitney and Gabler 2008). The testing

50 of theories blending ecological and evolutionary explanations can provide important insight into

51 how non-native plants are successful and how defense traits evolve; these tests often involve

52 comparison of genotypes from the native and non-native ranges (Orians and Ward 2010). Better

53 understanding of the mechanisms of non-native plant success may allow improved control and/or

54 more accurate predictions of the impacts that non-native species can have on native ecosystems.

55 Many hypotheses have been proposed to find a common reason for why plants successfully

56 invade non-native regions (Catford et al 2009), dating back to Darwin's naturalization hypothesis

57 (Diez et al 2008). Hypotheses have speculated on the potential for non-native plants to more

58 efficiently use resources than native plants (Coley et al 1985), or have proposed that non-native

59 plants are able to exploit an empty or less-crowded niche in the invaded habitat (Mack et al

60 2000; Hierro et al 2005). Many of these hypotheses also incorporate the idea that a competitive

61 advantage is gained through an enemy release in a non-native habitat from co-evolved, specialist

62 herbivores present in the native species range (Keane and Crawley 2002; Orians and Ward

63 2009). According to one prominent hypothesis, the evolution of increased competitive ability

64 (EICA) hypothesis, enemy release results in the allocation of resources to reproductive fitness

65

and/or competitive ability traits rather than to defenses. Relaxed selection for defense traits

66

would allow for the evolution of traits or trait values that allow plants to become more 
67 competitive and contribute to their invasive success (Blossey and Notzold 1995). Across a

68 gradient of invasion success native populations will express higher resistance and lower

69 allocation to competitive ability traits while the reverse, lower resistance and higher allocation to

70 competitive ability traits, is expected on the most successful non-native invaded site. For

71 instance, Blossey and Notzold (1995) found that plants in non-native populations of Lythrum

72 salicaria (Lythraceae) in eastern North America produced more seeds and had greater biomass

73 than those in native, European populations. Increases in seed production and biomass were

74 correlated with a decline in defenses against two specialist herbivores that, at the time, were not

75 present in eastern North America. By generating testable predictions of the role that ecology

76 plays in shaping the evolution of non-native plants, EICA hypothesis has become one of the most

77 widespread frameworks to explore the ability of non-native plants to succeed (Bossdorf et al

78 2005; Orians and Ward 2010).

79 Two specific, testable predictions of EICA to explain the success of non-native plant populations

80 include: Firstly, non-native populations will escape from coevolved specialist herbivores that

81 were present within the native range. This release from specialist herbivores should result in

82 relaxed selection pressure on specialist-related defense traits (e.g., Vila et al 2005). Secondly,

83 EICA predicts that there will be a trade-off between allocation of resources for resistance against

84 specialist herbivores and allocation to traits related to competitive ability. This shift to allow

85 more allocation to competitive ability traits (e.g. increased reproduction, large plants, etc.)

86 permits the non-native populations to compete successfully in their new habitat (Blossey and

87 Notzold 1995; Rotter and Holeski 2018).

88 Experimental tests of EICA can be complicated by a number of factors, including the difficulty

89 in knowing the most relevant defense traits against specialists, and inferring which competitive 
ability traits are most important in a particular non-native environment. Further, to test

91 evolutionary trade-offs, traits must be studied in a common garden environment, as the

92 measurement of phenotypes in the field yields trait values influenced by both genetic and

93 environmental variation. Perhaps in part because of these complications, there has been mixed

94 support for EICA (Bossdorf et al 2005; Felker-Quinn et al 2013; Rotter and Holeski 2018). For

95 example, in a recent meta-analysis that found some validation for EICA, evidence was strongest

96 when looking at actual herbivory (e.g. field damage or feeding trials), while there was very little

97 support when studies looked directly at resistance traits (Rotter and Holeski 2018).

98 While a number of studies have tested independent premises of EICA, fewer have conducted 99 simultaneous assessment of both resistance and competitive ability-related traits in a common 100 garden setting, which is necessary to detect evolutionary trade-offs particularly in a comparative 101 context between two invasions of relative age and success (Rotter and Holeski 2018). In 102 addition, very few studies have directly compared the accuracy of EICA predictions across 103 multiple invasions of the same species that differ in age and success. Here we test the predictions 104 of EICA in Mimulus guttatus, using populations in the native range of western North America, as 105 well as non-native populations in two areas of introduction, eastern North America and the 106 United Kingdom. Specifically we tested for:

1. An escape in non-native populations from co-evolved specialist herbivore species present in the native western North America range. This would be supported by the lack of specialist herbivores feeding on $M$. guttatus in the non-native populations in eastern North America and/or the United Kingdom. native. This would be demonstrated by reduced levels of genetic-based herbivore 
resistance traits, or in increased performance of herbivores feeding on non-native, vs. native plants.

\section{Methods}

Study system

Mimulus guttatus Fisch. ex DC. (Erythranthe guttata G.L. Nesom) is a species complex native to moist habitats throughout western North America (WNA). In the past few decades Mimulus spp. and in particular M. guttatus, have become important model organisms for the study of

132 evolutionary ecology and genetics (Wu et al 2008; Yuan 2018). Mimulus guttatus has been introduced throughout the globe where it has escaped numerous times from cultivation. Nonnative $M$. guttatus populations are located in the United Kingdom (UK), western Europe, New

135 Zealand, and eastern North America (ENA) (Hall and Willis 2006, Vallejo-Marin and Lye 2013). 
136 Historical records and genetic evidence suggest that the first $M$. guttatus introduced in the United 137 Kingdom originated from Alaska (referred to as cordilleran) (Puzey and Vallejo-Marin 2014).

138 The first records of naturalized $M$. guttatus in the UK are from the first half of the 1800 s and this 139 taxon is currently widespread and locally abundant in the UK (Preston et al 2002; Vallejo-

140 Marinand and Lye 2013; Puzey and Vallejo-Marin 2014). In contrast, it is unknown when $M$.

141 guttatus was first introduced into ENA, but we found no collections before the early 1900's and 142 most extant populations were observed since the 1960's. The source populations of the ENA 143 populations is currently uncertain, but they likely represent a mix of multiple accidental 144 introductions (e.g. through introduction of debris on military or construction equipment) and/or 145 cultivated escapes (Gleason and Cronquist 1991).

146 The degree of invasiveness differs between the UK populations and the ENA populations. For 147 instance, in particular areas of Europe there is concern over its spread into natural areas (Truscott 148 et al 2006) and new locations (Tokarska-Guzikand and Dajdok 2010). Within the United 149 Kingdom, the presence of $M$. guttatus is associated with local declines in native species richness 150 (Truscott et al 2008). In contrast, many of the reported populations in ENA appear to not be 151 spreading or have disappeared entirely (Timothy Block, personal communication, Gleason and 152 Cronquist 1991).

\section{Plant material}

154 We collected seed from wild populations in the summer of 2015, 2016, and 2017 in both the 155 native (WNA) and the non-native (ENA and the UK) regions (Figure 1, Table S1). Populations 156 were chosen to maximize geographic spread in all regions as well as to capture life history 157 variation across the M. guttatus range (e.g., annual and perennial populations). We also grouped 158 native populations into geographic clades (sub-regions in this paper) based on the genetic 
159 population structure results from Twyford and Friedman (2015) who found 5 broad genetic

160 clusters that were geographically separated. In each population, we collected seeds from $>20$

161 plants separated by at least a meter to avoid clones and from multiple flowers on each plant.

162 Populations were then grown in the greenhouse (Flagstaff AZ, USA) for at least one generation,

163 originating from multiple wild-collected, maternal sib families from each natural population.

\section{Herbivore communities}

165 The first prediction of EICA is that there is a release from specialist herbivore pressure in non166 native populations. To test for this prediction in M. guttatus, we collected herbivores at each seed

167 collection site and made herbivore collections from additional populations in each region. Most

168 sites were surveyed over at least two seasons. Plant damage was estimated at each field site as

169 the proportion of plants in the population with visible damage measured in a discrete scale (none:

170 no damage on any plant; low: 1-10\% of plants damaged by herbivores; moderate: $10-60 \%$ of

171 plants damaged; high: 60-90\% of plants damaged; extreme: $>90 \%$ of plants damaged). For

172 invertebrate herbivores, surveys consisted of timed visual searches and timed sweep netting (the

173 latter only when $M$. guttatus density was high enough to preclude herbivores on other plant

174 species). All invertebrates were collected and identified to the lowest taxonomic level possible.

175 Herbivores were considered as those animals seen actively feeding on a plant, or those on the

176 plant and likely able to feed on $M$. guttatus (such as a hemipteran resting on a plant but not

177 actively feeding). We also noted if the damage was caused by a mammal and any signs of what

178 mammal species may have been responsible. In addition to these field-based surveys in both

179 ranges, we conducted a literature review on reports of herbivores and noted their geographic 
181 related to M. guttatus (i.e., Scrophulariaceae sensu lato) to see if there were any specialist

182 herbivores that may be able to shift hosts onto M. guttatus in the non-native regions.

\section{Resistance traits}

184 Following a release from specialist herbivores, EICA predicts the evolution of lower levels of 185 some herbivore resistance traits. To test this part of EICA we used plants derived from native 186 and non-native populations to assess patterns of genetic- based trait variation from a common

187 greenhouse environment. We assessed specific leaf area (SLA), leaf water content, leaf dry 188 matter content (LDMC), trichome density, and foliar phytochemistry. After growing the plants in 189 a common greenhouse environment for one month, we harvested one leaf from the fourth true190 leaf pair. We weighed the leaf to get wet mass and then scanned the leaf (Epson Perfection V19) 191 to find leaf area using Image $\mathbf{J}$ (Rueden et al 2017). Freeze dried leaves (see below) were used to 192 estimate dry weight and calculate specific leaf area (SLA), leaf water content, and leaf dry matter content (LDMC). Leaf water content and LDMC are associated with performance of some

194 generalist herbivores consuming native $M$. guttatus (Rotter unpublished data) and have been 195 included as resistance traits in other EICA studies (Bossdorf et al. 2005). Trichome density was 196 measured by counting all the trichomes at the basal section of the adaxial side of each leaf within 197 the field of view of a dissecting microscope at 25x magnification. This density was converted to 198 trichome density per $\mathrm{cm}^{2}$ (Holeski 2007).

199 For phytochemical analysis, we quantified phenylpropanoid glycosides (PPGs), the predominant 200 foliar bioactive secondary compound in the species (Holeski et al 2013; Keefover-Ring et al 201 2014). The leaf opposite the leaf in feeding trials (detailed below) was cut at the base of the 202 petiole with scissors and flash frozen in liquid nitrogen before being transferred to a -20 degree C 203 freezer. Tissue was then lyophilized using a pre-chilled FreeZone triad freeze dry system 
204 (Labconco; Kansas City, USA). We finely ground the freeze-dried tissue in a small capacity ball mill (dental amalgamator with steel bearings). Samples were stored and extracted as described in Holeski et al. 2013. We quantified the PPG content of each sample via high-performance liquid 207 chromatography [HPLC; Agilent 1260 HPLC with a diode array detector and Poroshell 120 EC208 C18 analytical column (4.6 $250 \mathrm{~mm}, 2.7 \mu \mathrm{m}$ particle size); Agilent Technologies, Santa Clara, $209 \mathrm{CA}$ ] maintained at $30^{\circ} \mathrm{C}$, as described in Kooyers et al. (2017). The seven PPGs analyzed in this study represent the PPGs present in detectable levels in the populations used in this study.

Herbivore feeding trials

212 Herbivore response to plant resistance traits are often diffuse and vary depending on many

213 different factors. In addition to quantifying resistance traits, we also measured resistance though

214 two performance trials. For these trials, we used a subset of plant populations that represent the

215 range of native and non-native populations (Table S1). We conducted no-choice performance

216 trials with neonate Lepidopteran larvae of the specialist herbivore Junonia coenia and the

217 generalist herbivore Trichoplusia ni (Rotter and Holeski 2017; Rotter et al 2018). One leaf from

218 a leaf pair was placed in an envelope and treated as described above for analysis of PPGs. We

219 assessed trichome density on the second leaf of the leaf pair, as described in Holeski (2007). The

220 leaf scored for trichomes was then placed into a water pic and placed in a plastic container. In

221 each container, we placed a single recently emerged first instar caterpillar. Leaves were

222 immediately replaced with leaves from the same plant (with the opposite leaf harvested for

223 phytochemical analysis) if/when the caterpillar consumed the entire leaf or if the leaf wilted.

224 After larvae had fed for 10 days, we ended each trial, froze the caterpillars, and then dried and 225 weighed them to determine caterpillar final dry mass. Larval initial (wet) weights were all within $2260.001 \mu \mathrm{g}$ of each other for a particular species, so we assumed that initial dry mass was identical 
227 across larvae within each species. Higher caterpillar mass and growth rates are important

228 indicators of greater pupal survival rates as well as increased adult fitness (Haukioja and

229 Neuvonen 1985; Awmack and Leather 2002). Additionally, a more rapid growth rate allows

230 greater survival when faced with pressure from predators and parasitoids (Feeny 1976; Benrey

231 and Denno 1997).

$232 \quad$ Plant fitness traits

233 Finally, EICA predicts an increase in fitness/competitive ability traits with a release from

234 specialist herbivores and the decline of herbivore resistance traits. To test plant fitness traits we

235 used the plants from the resistance traits measurements. We grew all plants for a total of six

236 months prior to harvest with the exception of several populations of annual plants that were

237 harvested after they stopped producing flowers. We assessed traits related to reproductive

238 development, reproductive fitness, and vegetative fitness. We assessed reproductive development

239 by counting the number of days until a plant first flowered. We also measured the corolla width

240 (bigger flowers have been associated with pollinator preference; Martin 2004) of this first flower

241 on the day after it was fully emerged. We collected pollen from the first two flowers. Pollen was

242 then stained, counted, and evaluated for viability (decreased viability is a sign of inbreeding

243 depression within M. guttatus; Carr and Dudash 1995) with a hemocytometer following the

244 procedure in Kearns and Inouye (1993). We self-pollinated each plant with the next three

245 flowers, saturating each stigma with as much pollen as possible. Seeds were collected from these

246 flowers and total seed was counted. Finally, the total number of flowers produced by a plant

247 were counted at the time of plant harvest. Plants that did not flower by the end of the six-month

248 trial ( $\mathrm{n}=32$ plants) were excluded from these analyses. Vegetative traits quantified included

249 specific leaf area and leaf water content, which were measured as described above during our 
250 quantification of resistance traits. At harvest, we measured the total height (length) of the plant,

251 from the root crown to the end of the largest shoot. We then dried all plants in a drying oven and

252 measured aboveground biomass, belowground biomass, and total (aboveground + belowground)

253 biomass.

\section{Statistical analysis}

255 To compare herbivore communities, we used non-parametric multidimensional scaling (NMDS)

256 to look at herbivore family and functional feeding guild differences between native and non-

257 native populations of $M$. guttatus. The NMDS was performed using PC ORD v. 6 (McCune and

258 Mefford, 2016). We used Jaccard distance as the similarity measure, and the program was run on

259 "Autopilot" mode under the "slow and thorough" method, with principal axes rotation.

260 Significance of the ordination was based on a Monte Carlo test with 250 iterations. To validate

261 the NMDS we looked for differences between the non-native populations and the native sub-

262 regions in the above herbivore communities using multi-response permutation procedures

263 (MRPP). We also used ANOVA (transformed with either a log or root transformation as

264 assessed by Q-Q plots; we used Kruskal-Wallis tests if we could not obtain a normal

265 distribution) to look at the differences of field measured herbivory and herbivore richness

266 between regions and sub-regions. Trait values, fitness and resistance traits, were analyzed using a

267 nested ANOVA (plant family nested within population and population as a factor) to look for

268 differences between the two non-native ranges and the native geographical clades. We further

269 used Tukey post-hoc tests for pairwise comparisons between the non-native UK and ENA

270 populations and between the native subregions. Lastly, we wanted to test for the predicted

271 tradeoffs between herbivore resistance traits and competitive ability traits in the non-native

272 populations compared to native populations. To narrow down important traits as well as suits of 
273 traits we used PCA to find the two most important contributors to variation (components) for

274 resistance traits and then for fitness/competitive ability traits for the two introduced regions. We

275 took these components and used a linear regression (with population means of the components to

276 account for population structure) to look for the relationship between the PCA components for

277 resistance traits and the fitness/competitive ability PCA components. In addition to using the

278 PCA components, we used correlation matrices to look at all pairwise trait tradeoffs (using

279 population means) for each region. All ordinations and MRPPs were run in PC ORD v. 6

280 (McCune and Mefford 2016) with all other analysis conducted in R (ver. 3.1.1; R Core team 281 2013).

282 Results

283 Herbivores and herbivore communities

284 We found no evidence of specialist herbivores of $M$. guttatus in the non-native populations of the 285 UK or in ENA. Within both non-native regions, all herbivores found have not been reported to 286 consume plants from Scrophulariaceae sensu lato. However, the pool of potential specialist 287 species is greater in eastern North America than in the UK. For example, at several of the ENA 288 sites we observed adults of the specialists Euphydryas phaeton and Junonia coenia in the 289 proximity of the $M$. guttatus populations, although no caterpillars of these species were found 290 feeding on M. guttatus in ENA. Both species feed on plants related to M. guttatus and those that 291 share similar phytochemistry (i.e., PPGs) making it possible that they could select these plants 292 for oviposition with their offspring consuming the plants. In contrast we did not find any similar 293 occurrence in the UK populations. 
294 In the field, the percent of damaged plants differed between the regions and sub-regions $(\mathrm{H}=$ $2958.89, \mathrm{DF}=2, \mathrm{p}=0.012$, Figure $2 \mathrm{~A})$. We found three times fewer plants damaged in the invaded 296 UK than in the native WNA region (Dunns non-parametric comparison $\mathrm{p}<0.001$ ), while the 297 ENA populations had equivalent levels of field damage to the native WNA region (Dunns non298 parametric comparison $\mathrm{p}=0.154)$. The comparisons between the introduced populations and 299 individual native sub-regions showed that the UK populations had significantly less field 300 301 302 the non-native regions to the native sub-regions $\left(\mathrm{F}_{5,34}=2.33, \mathrm{p}=0.063\right)$.

Herbivore communities, at the family level, differed between the native subregions and the nonnative populations (MRPP A $=0.085, \mathrm{p}<0.001$, Table 1) with the two non-native regions (ENA and the UK) having similar herbivore families to one another $(\mathrm{A}=-0.017, \mathrm{p}=0.86$; Figure 3$)$. The similarity in herbivore communities in ENA and the UK was generally driven by families dominated by generalist herbivores such as terrestrial gastropods and mammals. Differences between the UK populations and the native Cordilleran populations (which includes Alaska and 312 is thus from which the UK populations are thought to be derived; $\mathrm{A}=0.092, \mathrm{p}<0.001$ ), were 313 driven in part by the lack of leaf mining Agromyzidae in the UK. Results of the MRPP supported 314 the results of the NMDS.

315 We also found substantial geographic variation in herbivore community composition within the native subregions. Native subregions were generally separated because of specialist insects that 
317 dominated in particular subregions. For instance, leaf mining Agromyzidae flies were common

318 in the cordilleran subregion as a dominant herbivore while the more southern subregions were

319 dominated by specialist caterpillar species. Herbivore functional feeding guild differences across

320 regions were similar to these herbivore community patterns (Table 1), and were driven by

321 generalist chewers being more common in the non-native regions.

\section{$322 \quad$ Herbivore resistance traits}

323 In comparing traits between non-native and native regions, we focus on trait comparisons

324 between populations from the non-native ENA and the native WNA regions and between the

325 non-native UK populations and their likely ancestral WNA Cordilleran subregion (see study

326 system for details). See the eastern North America supplement for a greater breakdown within

327 these and the native subregions.

328 We found mixed evidence of an overall relaxation of selection on resistance traits predicted by

329 EICA in the non-native $M$. guttatus populations. Physical resistance traits varied between native

330 and non-native regions. Trichome density was significantly different between all regions $\left(\mathrm{F}_{2,}, 518\right.$

$331=86.63, \mathrm{p}<0.001$, Figure 4). In support of EICA, native WNA populations had, on average,

332 three and a half times higher trichome density than the non-native ENA plants, which was

333 similar when using the native sub-regions $\left(\mathrm{F}_{5,516}=56.62, \mathrm{p}<0.001\right.$, Figure 4$)$. In contrast to the

334 predictions of EICA, the UK population had one and half times higher trichome density than the

335 native Cordilleran sub-region (Tukey post hoc: $\mathrm{p}=0.002$ ). Specific leaf area was not

336 significantly different between any of the native and non-native regions $\left(\mathrm{F}_{2,518}=1.82, \mathrm{p}=0.121\right.$,

337 Figure 4). Leaf water content in the UK populations was slightly higher than the Cordilleran

338 populations and the non-native ENA populations was slightly higher than the native WNA

339 populations $\left(\mathrm{F}_{2,517}=4.53, \mathrm{p}=0.011\right.$, Figure 4$)$, suggesting a relaxation in herbivore defense. Leaf 
340 dry matter content did not differ significantly across any of the native and non-native regions

$341 \quad\left(\mathrm{~F}_{2.517}=0.93, \mathrm{p}=0.392\right.$, Figure 4$)$.

342 Concentrations of chemical resistance compounds (PPGs) varied across the native and non-

343 native regions $\left(F_{2,454}=56.62, p=0.004\right.$, Figure 5). Potentially in contrast to EICA, the eastern

344 North American populations had higher levels of total PPGs than the native WNA plants (Tukey

345 post hoc: $\mathrm{p}=0.004)$. However, in line with the predictions of EICA, the non-native UK plants had

346 lower amounts of total PPG concentration than the native Cordilleran subregion. When

347 considering individual PPG compounds, there was no consistent overall pattern. For instance, the

348 non-native ENA plants had high concentrations of calceolarioside B relative to the native WNA

349 plants but a significantly lower concentration of verbascoside. Similarly, in the UK versus

350 Cordilleran comparison, the non-native UK plants had higher concentrations of calceolarioside B

351 than the cordilleran plants but lower concentrations of other PPGs such as conandroside (Figure

352 5).

353 We found no evidence that specialists herbivores performed better on plants from non-native

354 regions than from native, as predicted by EICA in lab trials. We found no difference in

355 performance of a generalist or a specialist herbivore feeding on tissue from native vs. non-native

356 regions. The generalist caterpillar Trichoplusia ni performed similarly on tissue from all regions

$357\left(F_{2,115}=0.06, p=0.940\right.$, Figure 6$)$, as well as between the non-native regions and native

358 subregions $\left(\mathrm{F}_{5,112}=1.73, \mathrm{p}=0.131\right)$. Performance of the specialist caterpillar Junonia coenia

359 also did not differ significantly across native and non-native regions $\left(\mathrm{F}_{2.41}=1.87, \mathrm{p}=0.168\right)$.

360 However, there were differences in J. coenia performance between the non-native regions and

361 the native subregions $\left(\mathrm{F}_{5,38}=2.77, \mathrm{p}=0.032\right)$ for instance caterpillars performed worse on the

362 ENA plants compared to the southern, northern, and cordilleran subregions. Both of the 
363 caterpillar species performed equally well on the native Cordilleran subregion plants and the

364 non-native UK plants. Interestingly, the generalist herbivore performed worst on the WNA

365 subregion in which the specialist herbivore species had the highest performance.

$366 \quad$ Fitness/competitive ability traits

367 Reproductive traits varied across plants from the native and non-native regions. The non-native

368 ENA populations tended to have relatively equivalent trait values for most traits when compared

369 to the native WNA populations. In contrast, the non-native UK populations deviated from the

370 Cordilleran subregion of WNA for many, but not all traits (Figure 7).

371 In the greenhouse, days till flower differed among regions $\left(F_{2,481}=27.28, p<0.001\right.$, Figure 7$)$.

372 However, the two non-native regions did not significantly differ from their native regions of

373 origin; the ENA plants flowered around the same time as the WNA plants (Tukey post hoc: $\mathrm{p}=$

374 0.761) and the UK plants flowered at the same time as the Cordilleran subregion plants (Tukey

375 post hoc: $\mathrm{p}=0.998$ ). In support of EICA, both non-native regions had on average larger corolla 376 widths than the native WNA region (Tukey post hoc: both $\mathrm{p}<0.001$ compared to WNA plants).

377 This same trend held when comparing the non-native regions to the native subregions $\left(\mathrm{F}_{5,481}=\right.$

$37835.83, \mathrm{p}<0.001$, Figure 7) with the UK plants having larger flowers than Cordilleran plants

379 (Tukey post hoc: $\mathrm{p}<0.001)$. While pollen viability was variable across regions $\left(\mathrm{F}_{2,381}=8.38, \mathrm{p}=\right.$

380 0.003, Figure 7), trends between regions were opposite those predicted by EICA. Pollen

381 viability was lower in the ENA populations than in the WNA as well as in the UK plants versus

382 the Cordilleran plants (Tukey post hoc: $\mathrm{p}>0.001$ for both comparison). Total flower production 383 was variable across regions $\left(\mathrm{F}_{2,518}=6.41, \mathrm{p}=0.001\right.$, Figure 7$)$. Conforming to EICA predictions, 384 the ENA plants produced slightly more flowers on average than WNA plants (Tukey post hoc: $p$ $385=0.007)$, and the UK populations produced on average one and half times more flowers than the 
native Cordilleran subregion (Tukey post hoc: $\mathrm{p}>0.001$ ). Finally, seed production varied across regions $\left(\mathrm{F}_{2,518}=5.83, \mathrm{p}=0.008\right.$, Figure 7$)$. The ENA plants produced an equivalent amount of seeds to the WNA plants (Tukey post hoc: $\mathrm{p}=0.064$ ). The UK populations produced twice as many seeds on average compared to the Cordilleran subregion (Tukey post hoc: $\mathrm{p}<0.001$ ).

For vegetative traits, plants from ENA tended to not conform to the predictions of EICA, while 391 the non-native UK populations did, for most but not all traits. Plant height varied across regions $\left(\mathrm{F}_{2,502}=50.92, \mathrm{p}<0.001\right.$, Figure 7$)$. Patterns in both non-native regions were compatible with the predictions of EICA. Plants from both the non-native ENA population and the UK population were larger than their native counterparts (Tukey post hoc: $\mathrm{p}<0.001$ ), with the UK plants being over twice as tall on average than the native Cordilleran subregion.

There was variation across the regions for total plant biomass (aboveground + belowground;

$397 \quad F_{2,503}=47.92, p<0.001$, Figure 7), as well as aboveground biomass and belowground biomass considered independently $\left(\mathrm{F}_{2,497}=55.36, \mathrm{p}<0.001 ; \mathrm{F}_{2,501}=12.03, \mathrm{p}<0.001\right.$, respectively $)$. The 399 non-native ENA populations had equivalent total, aboveground, and belowground biomass to the 400 native WNA populations (Tukey post hoc: $\mathrm{p}=0.899 ; \mathrm{p}=0.924 ; \mathrm{p}=0.941$, respectively). As

401 predicted by EICA, the UK populations had almost twice as much total biomass and 402 aboveground biomass, and also higher root biomass than the Cordilleran subregion (Tukey post 403 hoc: $\mathrm{p}<0.001$ for all biomass comparisons).

404 Shoot to root ratios varied across regions $\left(\mathrm{F}_{2,497}=14.36, \mathrm{p}<0.001\right.$ Figure 7$)$, with the non-native 405 ENA populations having the largest ratio, which was significantly larger than that for WNA 406 (Tukey post hoc: $\mathrm{p}=0.002$ ). Shoot:root ratios for the UK populations were equivalent to those of 407 the Cordilleran populations (Tukey post hoc: $\mathrm{p}=0.625$ ). 
409 We found some evidence of resistance-fitness/competitive ability trade-offs in the non-native

410 UK region. For herbivore resistance traits, PCA one (24.8\%) was associated with chemical traits

411 such as conandroside, calceolarioside A and B, and unknown PPG 16. The second component

$412(15.8 \%)$ was associated with trichome density, SLA, and unknown PPG 10. For

413 fitness/competitive traits, PCA one (28.5\%) was associated with plant height, number of flowers,

414 and pollen viability while component two was associated with days till first flower, corolla

415 width, and root mass. We found negative associations (suspected tradeoffs) between

416 fitness/competitive ability PCA component one and resistance traits PCA component two $\left(\mathrm{R}^{2}=\right.$

$417 \quad 0.29, \mathrm{p}=0.012$; Figure 8). Additionally, we found a positive relationship between

418 fitness/competitive ability component two and resistance component one $\left(R^{2}=0.17, p=0.045\right)$.

419 The other regressions had non-significant relationships (Table 2).

420 We found no signs of resistance-fitness/competitive ability trade-offs in the ENA plants. The

421 PCA for resistance traits in the ENA plants had the first component (25\%) associated with

422 conandroside, calceolarioside A, and unknown PPG 16 with the second component (20.9\%)

423 associated primarily with verbascoside, mimuloside, and unknown PPG 10. The fitness/

424 competitive traits PCA had a first component (40\%) associated primarily with number of

425 flowers, shoot mass, and corolla width. The second component (18.8\%) was associated with root

426 mass, pollen viability and seed production. All the components had non-significant relationships

427 to one another (Table 2).

428 The native region (WNA) also showed evidence of resistance vs. fitness/competitive ability

429 tradeoffs. Herbivore resistance PCA first component (21.2\%) was associated with unknown PPG

43016 , calceolarioside B, and conandroside while the second component (14\%) was associated with 
431 calceolarioside A, unknown PPG 10, and mimuloside. The first component (33.3\%) for fitness/

432 competitive ability traits was composed primarily of corolla width, plant height, and shoot mass.

433 The second component (16.5\%) was associated with days till first flower, number of flowers, and

434 pollen viability. The only significant relationship we found for WNA plants was a negative

435 relationship between fitness/competitive ability component two and resistance component one

$436\left(\mathrm{R}^{2}=0.16, \mathrm{p}=0.041\right.$, Figure 8$)$. All other comparisons were non-significant (Table 2).

437 Finally, Cordilleran plants showed no signs of tradeoffs. The herbivore resistance PCA

438 component one (25.6\%) was associated with unknown PPG 16, calceolarioside A, and

439 conandroside and the second component (16.9\%) was associated with calceolarioside B,

440 verbascoside, and unknown PPG 10. The first component of the fitness/ competitive ability traits

441 (41.9\%) was associated with corolla width, plant height, and number of flowers produces, the

442 second fitness/ competitive ability component (23.4\%) was associated with root mass, seed

443 count, and percent pollen viability. We found no evidence of tradeoffs between these

444 components (Figure 8, Table 2). In addition to regression results we also detected weak signs of

445 tradeoffs between specific resistance traits and competitive/ fitness traits through correlation

446 analysis. There results are similar to the regression results (Figures S1-S3).

\section{Discussion}

448 By comparing two different plant invasions of differing ages to their native counterparts we 449 found some, but not comprehensive, support for EICA. Support was strongest in the non-native

450 UK, the older and more successful of the two invasions. Both the non-native UK and the ENA

451 plants had different herbivore communities than the native WNA plants. However, there was

452 adherence to the EICA prediction of a reduction in herbivore damage as well as clear evidence of

453 specialist herbivore escape in only the UK range. We found relatively minor support for the 
454 prediction that there would be a decline of herbivore resistance traits in the non-native plants,

455 with some changes in trait values in the non-native vs. native regions, but no differences in

456 herbivore performance in no-choice trials. The UK plants were larger, taller, and produced more

457 seeds and flowers than their native counterparts, in accordance with EICA predictions, while the

458 non-native ENA plants were generally smaller and had poorer pollen production than the native

459 WNA plants. Lastly the UK plants exhibited some tradeoffs between resistance traits and fitness/

460 competitive ability while the ENA plants did not, confirming the predictions that release from

461 specialist herbivores can result in allocational tradeoffs that allow for increases in fitness/

462 competitive ability.

463 Enemy release and resistance traits in the non-native populations

464 We found some evidence of escape from coevolved specialist herbivores in both of the non-

465 native regions. However, this did not translate to the same pattern of relaxed defenses in the two

466 non-native regions. Each non-native region had several resistance traits present at lower levels

467 than in their native ancestral regions. The non-native ENA populations had lower trichome

468 density and higher leaf water content than did the native WNA populations, while the non-native

469 UK populations had higher leaf water content and lower levels of total PPGs than the native

470 Cordilleran region. However, levels of some defenses were also higher in the non-native regions

471 than the native, and we found no difference in performance of generalist and specialist

472 herbivores feeding on native vs. non-native plants. Within a non-native range, even if they are

473 escaping co-evolved specialist herbivores, introduced plants often encounter generalist

474 herbivores that may prefer to attack these non-native plants (Maron and Vilà 2001; Parker and

475 Hay 2005; Liu et al 2007). One of the few other studies that have compared two invaded regions

476 within the context of EICA found that populations of the invasive plant Senecio jacobaea in a 
477 region with a biological control agent (i.e. re-association with a specialist herbivore, see also

478 Sieman and Rogers 2003 and Valverde et al. 2015) did not conform to EICA predictions as well

479 as an invaded region without this control agent present (Rapo et al 2010). Both non-native ranges in our study had different herbivores communities attacking them than the native region,

481 although herbivory pressures were not necessarily lessened in the non-native environments.

482 Plants in ENA still suffered equivalent damage to WNA plants while, although they suffered less 483 damage, UK plants still had equivalent herbivore richness (per population) as the native plants 484 did. Another explanation of these results may stem from the longevity of the UK invasion versus 485 the relatively new ENA invasion. The UK plants may have initially experienced a herbivore 486 release that was reduced or eliminated over time, and thus may have evolved a new defense 487 strategy most effective in the current habitat.

488 Although other studies have generally detected EICA-predicted relaxation of resistance to 489 specialist herbivores in non-native regions in feeding trials (Rotter and Holeski 2018), these 490 changes in herbivore resistance traits were not detected in herbivore performance trials in our 491 study. An alternative hypothesis, the novel weapons hypotheses (Callaway and Ridenour 2004; 492 Inderjit et al 2006), which predicts that enemy release and non-native success is the result of the 493 non-native plants unique chemical unpalatability to herbivores in the non-native range, may 494 explain the lack of differences between caterpillar performance. This would suggest that the non495 native populations may have retained resistance traits because they are beneficial in the non496 native region. The presence of overlap in resistance traits, as some traits likely deter both 497 generalists and specialists, resulting in the overall maintenance of traits that defend against 498 generalist herbivores. This would lead to the maintenance of certain resistance traits that may 499 deter specialist herbivores despite their absence. For instance, the PPG conandroside has a 
500 negative impact on the performance of the generalist herbivores Grammia incorrupta and

501 Spodoptera exigua as well as a negative impact on the specialist herbivore Junonia coenia

502 (Rotter et al 2018).

503 Changes to competitive ability in non-native plants

504 The EICA prediction that trait values related to fitness and/or competitive ability will be higher 505 in non-native regions was partially supported by our data. Like resistance traits, we did not see 506 similar patterns in fitness and/or competitive ability traits between the two non-native regions. 507 Fitness/competitive ability traits tended not to conform to the predictions of EICA for the non508 native ENA region; these trait values were generally very similar to those for the native WNA 509 region. In contrast, fitness/competitive ability trait values were greater in the non-native UK than 510 the native Cordilleran region for many traits, in accordance to EICA predictions. Several other 511 studies have looked at genetic-based phenotypic differences, particularly physiological and floral 512 traits, between native and non-native M. guttatus (van Kleunen and Fischer 2008; Murren et al 513 2009; Martinez 2018). In these studies there was an observed adaptation of the non-native plants 514 to local abiotic conditions as well as producing more flower-bearing stems (van Kleunen and 515 Fischer 2008) with non-native plants exhibiting increased flower sizes (Murren et al 2009), 516 which is similar to our findings in the UK plants. For competitive traits, relative growth rate was 517 not found to be different between native and non-native $M$. guttatus populations (Martinez 518 2018). In the UK, M. guttatus has been shown to readily spread through both vegetative and seed 519 propagules during high flow events allowing for successful spread (Truscott et al 2006), although 520 this study focused on non-native populations and did not include a native population comparison.

$521 \underline{\text { Tradeoffs }}$ 
522 We found equivocal support for EICA-predicted trade-offs between defense and

523 fitness/competitive ability. In the native WNA and non-native ENA comparison, there were

524 actually fewer detected trade-offs in the non-native region (0) than in the native (1). The native

525 Cordilleran vs. non-native UK comparison was compatible with EICA, with no trade-offs

526 detected in the native region, and one detected in the non-native UK. EICA's predictions for the

527 success of non-native plants are based on the assumption of allocational tradeoffs existing

528 between herbivore resistance and traits associated with competitive ability (Bloosey and Notzold

529 1995; Orians and Ward 2008). Here, we did find an increase in trait values for traits associated

530 with fitness/competitive ability in one non-native range (the UK), but these increases were not

531 overwhelmingly associated with decreases in resistance traits. A recent meta-analysis found that

532 non-native plants may in fact not have to make these trade-offs and instead are able to increase

533 resistance traits and fitness/competitive ability (Rotter and Holeski 2018). This may present

534 some support for hypotheses predicting that non-native plants are able to exploit resources more

535 efficiently or take advantage of unoccupied niche space (Burke and Grime 1996; Davis et al

536 2001). In fact, there may be a synergy between enemy release and the use of resources as species

537 that are limited by defending themselves may gain a significant advantage when these resources

538 are in abundance (Blumenthal 2006).

539 This lack of clear tradeoffs, as predicted by EICA, has also been found in other reviews focused

540 on EICA (Bossdorf et al 2005; Felker-Quinn et al 2013). Both of these studies found overall that

541 non-native plant populations changed in their herbivore resistance traits as well as their fitness/

542 competitive ability traits but these changes did not reflect EICA predictions of a tradeoff (a direct

543 relationship between an increase in fitness/ competitive ability and a decrease in herbivore

544 resistance traits). These studies suggested that more specific looks at relevant traits was needed 
545 in testing EICA predictions. Although it is possible that we missed some of the key traits that are

546 involved in tradeoffs, our study was relatively comprehensive in our trait selection particularly

547 for traits important to the ecology of M. guttatus.

548 Can EICA predict the success of $M$. guttatus invasions?

549 Finally, our prediction that the more successful and older invasion (the UK) would display more 550 evidence of adherence to EICA than the less successful and recent invasion (ENA), was

551 supported. The non-native UK populations showed greater adherence to multiple predictions of

552 EICA (Table 3) than the non-native ENA region. Within the EICA framework, species that have 553 become extremely successful invaders such as Triadica sebifera (Huang et al 2010; Carillo et al 554 2014) might conform more closely to EICA than relatively non-invasive non-natives such as 555 Lepidium draba (Cripps et al 2009). In the UK, M. guttatus has successfully spread throughout 556 the country filling many of the available niches. In ENA the invasion is thought to be more 557 recent, $M$. guttatus has become extirpated from several of the locales where it has previously 558 been reported, and no new populations have been reported since at least the early 2000's. Our 559 results correspond with those of other studies that compared different non-native plants within 560 the same region that had differing level of invasiveness (ability to spread and dominate 561 communities). Plants that were ranked as more invasive had lower rates of herbivory than those 562 non-natives that were not considered as invasive (Cappuccino and Carpenter 2005). This 563 supports the idea that the strongest evidence for EICA may be found in more successful 564 invasions.

565 The relative success of the UK invasion versus the ENA invasions and the differences in 566 adherence to EICA across invasions may be in part explained by the nature of their introductions. 567 The UK plants were introduced as a garden plant; these plants are typically pre-selected in the 
568 field for traits correlated with increased fitness/ competitive ability (Reichard and White 2001;

569 Dehnen-Schmutz et al 2007). In contrast, the ENA plants most likely came from multiple

570 haphazard introductions. In addition to these pre-selected traits UK plants have had more time to

571 be influenced from the new herbivore communities and respond to evolutionary tradeoffs. This

572 lag time is somewhat common in other non-native plant invasions (Crooks 1999) and could

573 explain the greater conformity of the UK populations to the EICA predictions. It is possible that

574 given more time the ENA plants will become more successful and their relative adherence to

575 EICA predictions may also change.

576 There are many different frameworks for understanding the success of non-native organisms

577 (Catford et al 2009) and it is likely that there is not a single one that can consistently and fully

578 explain why a non-native species becomes successful across systems (Gurevitch et al 2011; Lau

579 and Schultheis 2015). This is the case with our results; although we found some evidence to

580 support EICA, particularly in the non-native UK region, there were several patterns that were not

581 necessarily compatible with EICA (e.g., caterpillar performance was not different between the

582 native and non-native plants and the sometimes positive relationship between resistance traits

583 and fitness/ competitive ability in the UK plants). However, we do present evidence that the

584 release from (or at least a shift in herbivore suites) can lead to evolutionary changes in plant

585 resistance traits that result in an increase in competitive ability particularly in invasions that have

586 persisted longer and have achieved higher success.

588 Acknowledgments

589 We thank the members of the Holeski lab group for assistance on various parts of this project.

590 Phil Patterson helped with plant cultivation in the greenhouse. Thanks to Dean Robinson who let

591 us study the plants on his property. Comments from Dr. Tom Whitham and Dr. Richard

592 Hofstetter improved this manuscript. Funding was provided by the NAU genes to environment 
fellowship program and the NAU Department of Biological Sciences. A special thanks to funding from the Michigan Botanical Foundation, Idaho Native Plant Society, and the Utah Native Plant Society.

\section{Compliance with ethical standards}

The authors declare no conflicts of interests.

\section{References}

Awmack CS, Leather SR (2002) Host plant quality and fecundity in herbivorous insects. Annu rev of entomol 47:817-844

Benrey B, Denno RF (1997) The slow-growth-high-mortality hypothesis: a test using the cabbage butterfly. Ecology 78: 987-999.

Blossey B, Notzold R (1995) Evolution of increased competitive ability in invasive nonindigenous plants: a hypothesis. J. Eco 83: 887-889

Bossdorf O, Auge H, Lafuma L, Rogers WE, Siemann E, Prati D. (2005) Phenotypic and genetic differentiation between native and introduced plant populations. Oecologia 144: 1-11

Callaway RM, Maron JL. 2006. What have exotic plant invasions taught us over the past 20 years?. Trends Eco Evo 21: 369-374

Carr DE, Dudash MR (1995) Inbreeding depression under a competitive regime in Mimulus guttatus: consequences for potential male and female function. Heredity 75: 437-443

Carrillo J, McDermott D, Siemann E (2014) Loss of specificity: native but not invasive populations of Triadica sebifera vary in tolerance to different herbivores. Oecologia, 174: 863-871

Carson WP, Hovick SM, Baumert AJ, Bunker DE, Pendergast TH (2008) Evaluating the post-release efficacy of invasive plant biocontrol by insects: a comprehensive approach. Arthropod-Plant 2: 77-86

Catford JA Jansson R, Nilsson C (2009) Reducing redundancy in invasion ecology by integrating hypotheses into a single theoretical framework. Divers Distrib 15: 22-40

Colautti RI, Ricciardi A, Grigorovich IA, MacIsaac HJ (2004) Is invasion success explained by the enemy release hypothesis?. Ecol Lett 7:721-733

Coley PD, Bryant JP, Chapin FS (1985) Resource availability and plant antiherbivore defense. Science 230: 895-899

Cox GW (2004) Alien species and evolution: the evolutionary ecology of exotic plants, animals, microbes, and interacting native species. Island Press

Cripps MG, Hinz HL, McKenney JL, Price WJ, Schwarzländer M (2009) No evidence for an 'evolution of increased competitive ability for the invasive Lepidium draba. Basic App Ecol 10: 103-112 
Crooks JA, Soulé ME, Sandlund OT (1999) Lag times in population explosions of invasive species: causes and implications. In Invasive species and biodiversity management, Kluwer Academic Publishers, Boston MA, USA.

Daehler CC (2001) Darwin's naturalization hypothesis revisited. Am Nat 158: 324-330

Dehnen-Schmutz K, Touza J, Perrings C, Williamson M (2007) A century of the ornamental plant trade and its impact on invasion success. Divers Distrib 13: 527-534

Diez JM, Sullivan JJ, Hulme PE, Edwards G, Duncan RP (2008) Darwin's naturalization conundrum: dissecting taxonomic patterns of species invasions. Eco Lett 11: 674-681

Elton CS (1958) The ecology of invasions by animal and plants. Methuen publishers

Feeny P (1976) Plant apparency and chemical defense. In Biochemical interaction between plants and insects (pp. 1-40). Springer, Boston, MA.

Felker-Quinn E, Schweitzer JA, and Bailey JK (2013) Meta-analysis reveals evolution in invasive plant species but little support for Evolution of Increased Competitive Ability (EICA). Eco Evo 3: 739-751

Fortuna TM, Eckert S, Harvey JA, Vet LE, Müller C, Gols R (2014) Variation in plant defences among populations of a range-expanding plant: consequences for trophic interactions. New Phyt 204: 989-999

Gleason HA, Cronquist A (1963) Manual of vascular plants of northeastern United States and adjacent Canada. New York: Van Nostrand

Gurevitch J, Fox GA, Wardle GM, Taub D (2011) Emergent insights from the synthesis of conceptual frameworks for biological invasions. Eco Lett 14: 407-418

Haukioja E, Neuvonen S (1985) Induced long-term resistance of birch foliage against defoliators: defensive or incidental?. Ecology 66: 1303-1308

Hierro JL, Maron JL, Callaway RM (2005) A biogeographical approach to plant invasions: the importance of studying exotics in their introduced and native range. J. Eco 93: 5-15

Holeski LM (2007) Within and between generation phenotypic plasticity in trichome density of Mimulus guttatus. J. Evo Bio 20: 2092-2100

Holeski LM, Keefover-Ring K, Bowers MD, Harnenz ZT, Lindroth RL (2013) Patterns of phytochemical variation in Mimulus guttatus (yellow monkeyflower). Chem Eco 39: 525-536.

Huang W, Siemann E, Wheeler GS, Zou J, Carrillo J, Ding J (2010) Resource allocation to defence and growth are driven by different responses to generalist and specialist herbivory in an invasive plant. J. Eco 98: $1157-1167$

Inderjit, Callaway RM, Vivanco JM (2006) Can plant biochemistry contribute to understanding of invasion ecology?. Trends Plant Sci 11:574-580

Jeschke JM, Gómez Aparicio L, Haider S, Heger T, Lortie CJ, Pyšek P, Strayer DL (2012) Support for major hypotheses in invasion biology is uneven and declining. NeoBiota 14: 1-20

Keane RM, Crawley MJ (2002) Exotic plant invasions and the enemy release hypothesis. Trends in Ecol Evol 17: 164-170 

glycosides of Mimulus guttatus (yellow monkeyflower). Phytochem Lett 10: 132-139

665 Kelly JK, Rasch A, Kalisz S (2002) A method to estimate pollen viability from pollen size variation. Ame 666 J of Bot 89: 1021-1023

667 Kooyers NJ, Blackman BK, Holeski LM (2017) Optimal defense theory explains deviations from 668 latitudinal herbivory defense hypothesis. Ecology 98: 1036-1048

669 Lankau RA (2007) Specialist and generalist herbivores exert opposing selection on a chemical defense. 670 New Phyt 175: 176-184

671 Lau JA, Schultheis EH (2015) When two invasion hypotheses are better than one. New Phyt 205: 958672960

673 Liu H, Stiling P, Pemberton RW (2007) Does enemy release matter for invasive plants? Evidence from a 674 comparison of insect herbivore damage among invasive, non-invasive and native congeners. Bio Inv 9: $675 \quad 773-781$.

676 Mack RN, Simberloff D, Lonsdale MW, Evans H, Clout M, Bazzaz FA (2000) Biotic invasions: causes, 677 epidemiology, global consequences, and control. Eco App 10: 689-710

678 Maron JL, Vilà M (2001) When do herbivores affect plant invasion? Evidence for the natural enemies and 679 biotic resistance hypothesis. Oikos 95: 361-373

680 Martin NH (2004) Flower size preferences of the honeybee (Apis mellifera) foraging on Mimulus guttatus 681 (Scrophulariaceae). Evo Eco Res 6: 777-782

682 Martinez KA (2018) Comparative Ecophysiology of Native and Invasive Plants across Populations, 683 Species, and Continents (Doctoral dissertation, Syracuse University).

684 McCune B, Mefford MJ (2011) PC-ORD: Multivariate analysis of ecological data. MjM Software 685 Design.

686 Minchin PR, (2018) Non-metric multidimensional scaling of community data: Myths and misconceptions. 687 Paper presented at the Ecological Society of America, $103^{\text {rd }}$ Annual meeting, New Orleans Louisiana 688 August $5^{\text {th }}-8^{\text {th }}$

689 Müller-Schärer H, Schaffner U, Steinger T (2004) Evolution in invasive plants: implications for 690 biological control. Trends Eco and Evol 19: 417-422

691 Murren CJ, Chang CC, Dudash MR (2009) Patterns of selection of two North American native and 692 nonnative populations of monkeyflower (Phrymaceae). New Phyt 183: 691-701

693 Myers J, Myers JH, Bazely D (2003) Ecology and control of introduced plants (Vol. 62). Cambridge 694 University Press.

695 Orians CM, Ward D (2010) Evolution of plant defenses in nonindigenous environments. Annu rev of 696 entomol 55: 439-459

697 Parker JD, Hay ME (2005) Biotic resistance to plant invasions? Native herbivores prefer non-native 698 plants. Eco Let 8: 959-967 
Preston CD, Pearman DA Dines TD (2002) New Atlas of the British and Irish Flora. Oxford University Press, Oxford.

R Core Team (2013) R: A language and environment for statistical computing. R Foundation for Statistical Computing, Vienna, Austria. URL http://www.R-project.org/.

Reichard SH, White P (2001) Horticulture as a pathway of invasive plant introductions in the United States: most invasive plants have been introduced for horticultural use by nurseries, botanical gardens, and individuals. BioScience 51: 103-113

Rejmánek M, Richardson DM, Pyšek P (2013) Plant invasions and invasibility of plant communities. Vegetation ecology, Blackwell Publishing

Richardson DM, Pyšek P (2006) Plant invasions: merging the concepts of species invasiveness and community invasibility. Prog Phys Geo 30: 409-431

Rotter MC, Holeski LM (2018) A meta-analysis of the evolution of increased competitive ability hypothesis: genetic-based trait variation and herbivory resistance trade-offs. Bio Invas 20: 2647-2660

Rotter MC, Couture JJ, Rothwell EM, Garcia J, Holeski LM (2018) Evolutionary ecology of plant resistance traits across the herbivore diet spectrum: a test in the model plant Mimulus guttatus. Evo Eco Res 19: 423-440

Rueden CT, Schindelin J, Hiner MC, DeZonia BE, Walter AE, Arena ET, Eliceiri KW (2017) ImageJ2: ImageJ for the next generation of scientific image data. BMC bioinformatics 18: 529

Siemann E, Rogers WE (2003) Increased competitive ability of an invasive tree may be limited by an invasive beetle. Eco App 13: 1503-1507

Stace C (2010) New flora of the British Isles. Cambridge University Press.

Truscott AM, Palmer SC, Soulsby C, Westaway S, Hulme PE (2008) Consequences of invasion by the alien plant Mimulus guttatus on the species composition and soil properties of riparian plant communities in Scotland. Perspect Plant Ecol System 10: 231-240

Truscott AM, Soulsby C, Palmer SCF, Newell L, Hulme PE (2006) The dispersal characteristics of the invasive plant Mimulus guttatus and the ecological significance of increased occurrence of high-flow events. J Eco 94: 1080-1091

Vallejo-Marin M, Lye GC (2013) Hybridisation and genetic diversity in introduced Mimulus (Phrymaceae). Heredity 110: 111-122

Valverde PL, Arroyo J, Núñez-Farfán J, Castillo G, Calahorra A, Pérez-Barrales R., Tapia-López R (2015) Natural selection on plant resistance to herbivores in the native and introduced range. AoB 7:230240

van Kleunen M, Fischer M (2008) Adaptive rather than non-adaptive evolution of Mimulus guttatus in its invasive range. Basic Appl Ecol 9: 213-223

Vila M, Maron JL, Marco L (2005) Evidence for the enemy release hypothesis in Hypericum perforatum. Oecologia, 142: 474-479

Wolfe LM (2002) Why alien invaders succeed: support for the escape-from-enemy hypothesis. Amer Nat 160: $705-711$ 
737 Wu CA, Lowry DB, Cooley AM, Wright KM, Lee YW, Willis JH (2008) Mimulus is an emerging model 738 system for the integration of ecological and genomic studies. Heredity 100: 220-230

739 Yuan YW (2018) Monkeyflowers (Mimulus): new model for plant developmental genetics and evo-devo. 740 New Phyt, 1-7

741 Zheng YL, Feng YL, Zhang LK, Callaway RM, Valiente-Banuet A, Luo DQ, Silva-Pereyra C 2014

742 Integrating novel chemical weapons and evolutionarily increased competitive ability in success of a

743 tropical invader. New Phyt 205: 1350-1659

744

745

746

747

748

749

750

751

752

753

754

755

756

757

758

759

760

761

762

763

764

765

766

$767 \quad$ Figures 


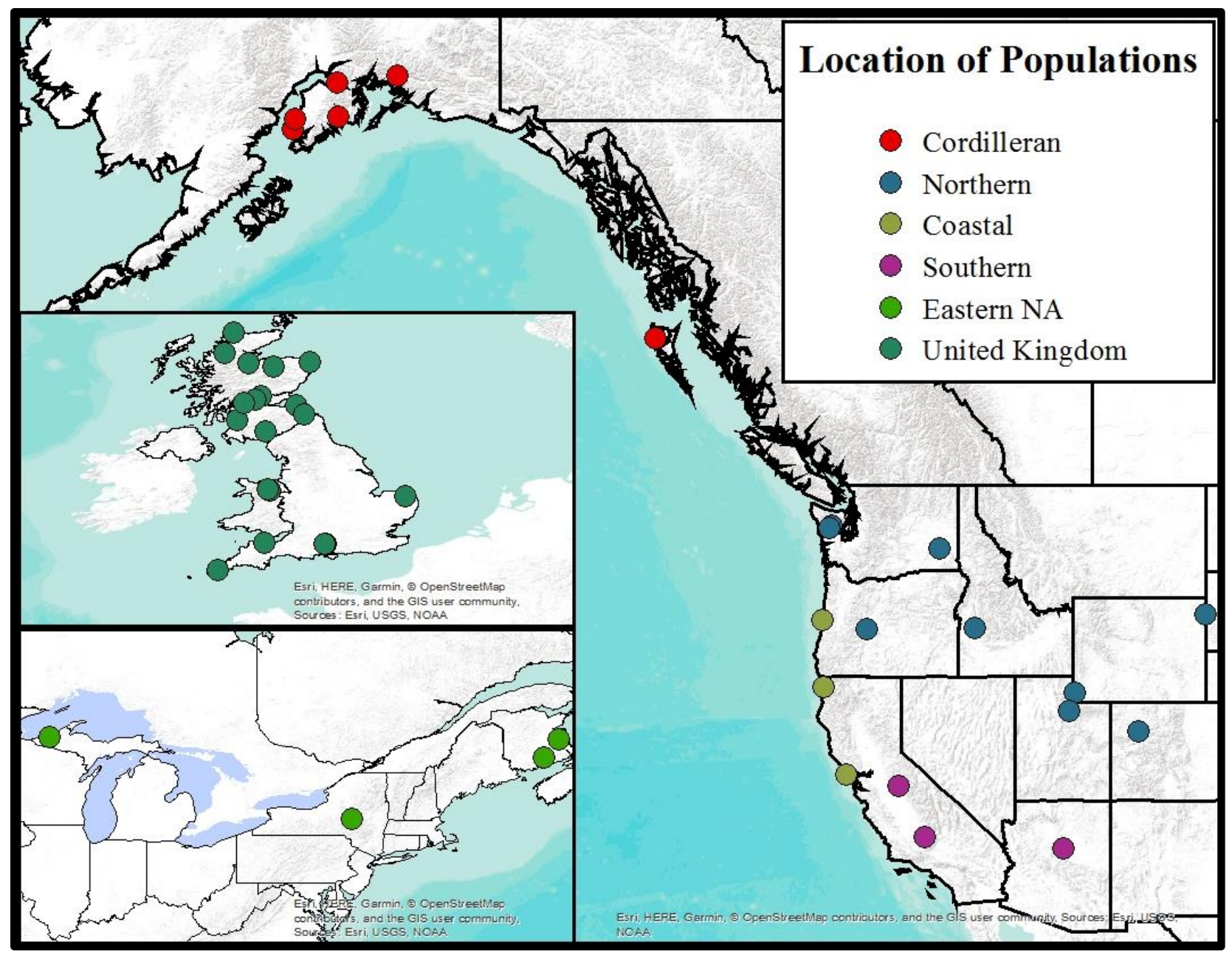

Figure 1. Locations of populations used in this study. Sub-regions within the native range (W. North 

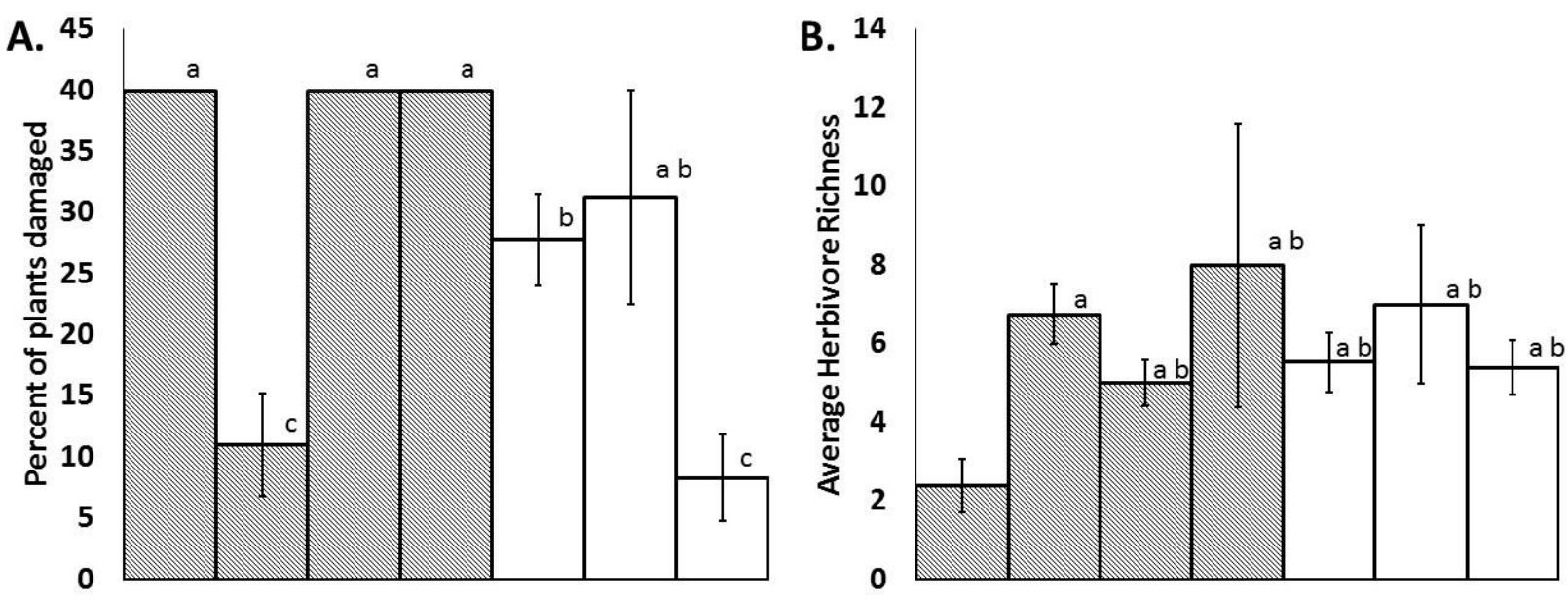

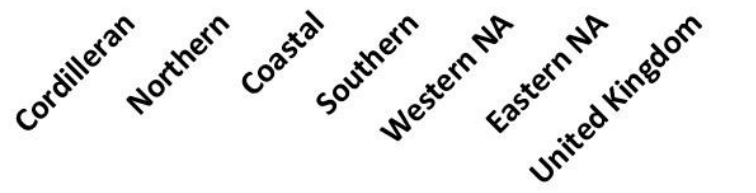

Region and Subregion of Mimulus guttatus populations

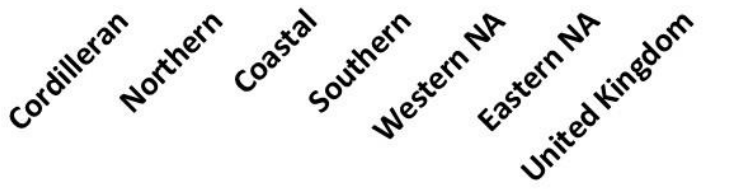

Region and Subregion of Mimulus guttatus populations

772 Figure 2. A. Percent of plants with herbivore damage in wild growing Mimulus guttatus populations between regions (in white) and native subregions (patterned). B. Average herbivore species richness found in the field feeding on Mimulus guttatus populations between regions (in white) and native subregions (patterned). Error bars represent \pm 1 standard error. Letters indicate equivalent values based on a Tukey HSD post-hoc test. Non-transformed data displayed. 


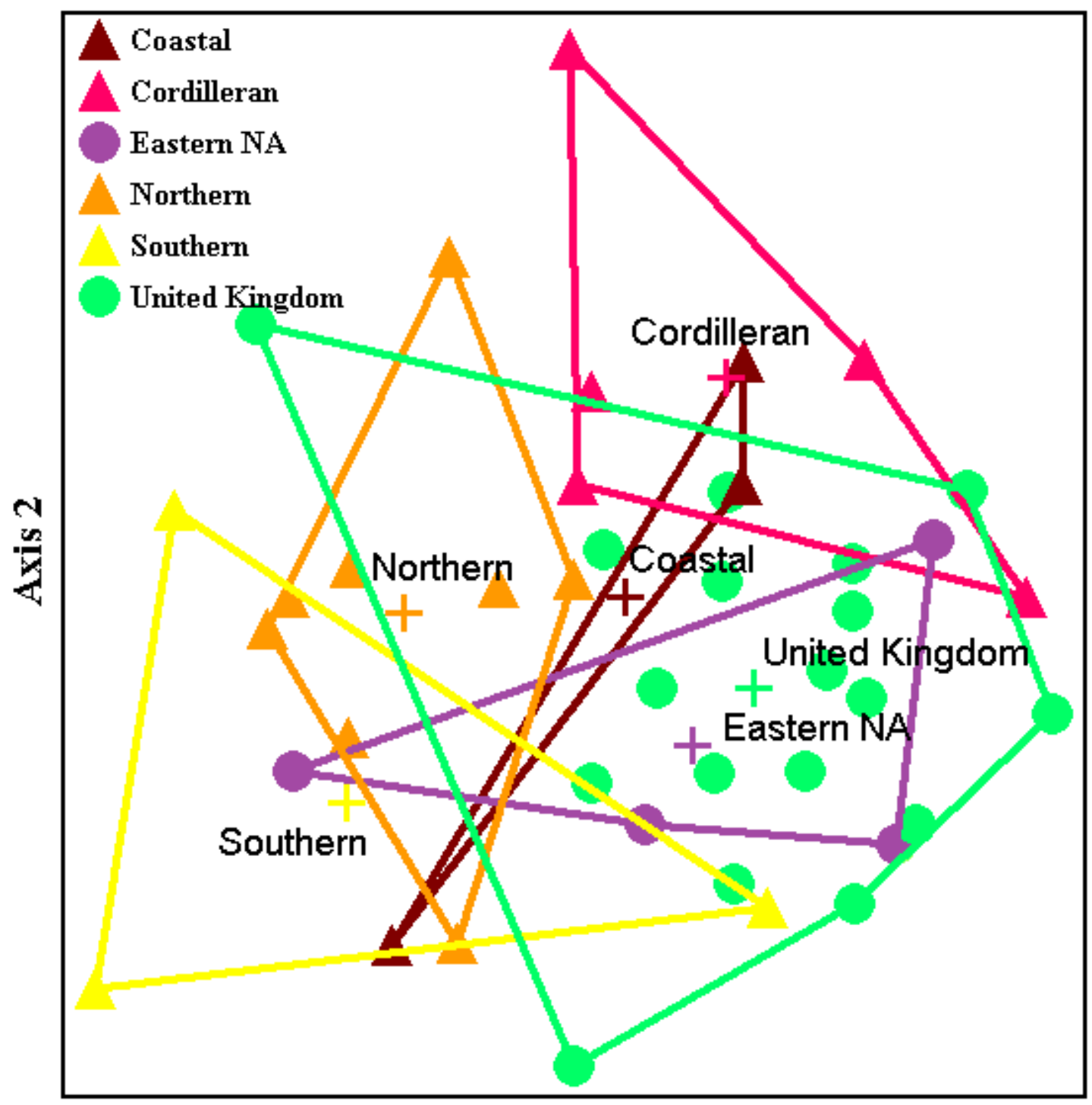

Axis 1

Figure 3. NMDS of herbivore communities based on family for the two non-native regions and the four native subregions. A 2D solution was the best solution with final stress being 25.71. Stress of axis 1 was 51.74 and axis 2 was 27.891. Although there is high stress, these results resembles MRPP results and are ecologically relevant (See Minchin 2018). 
A.

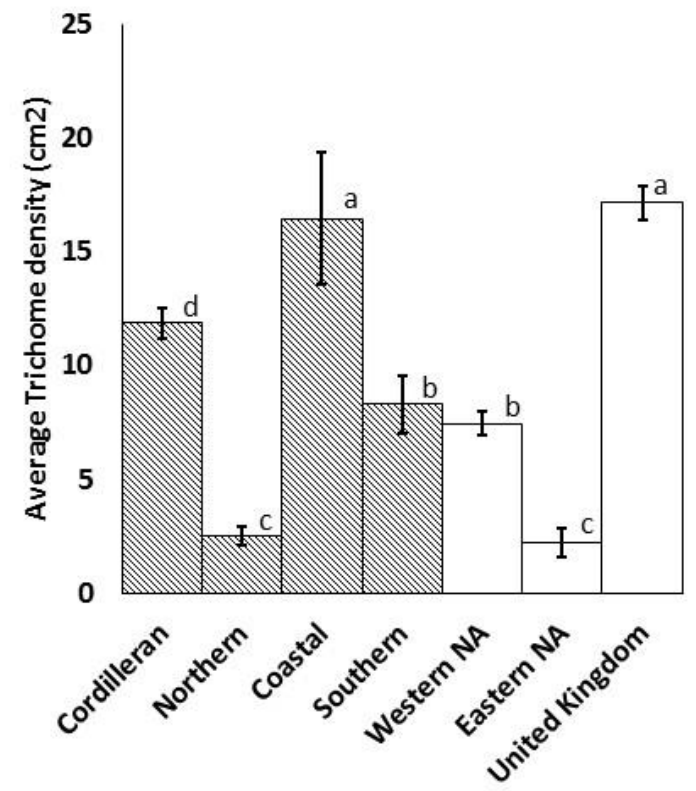

c.

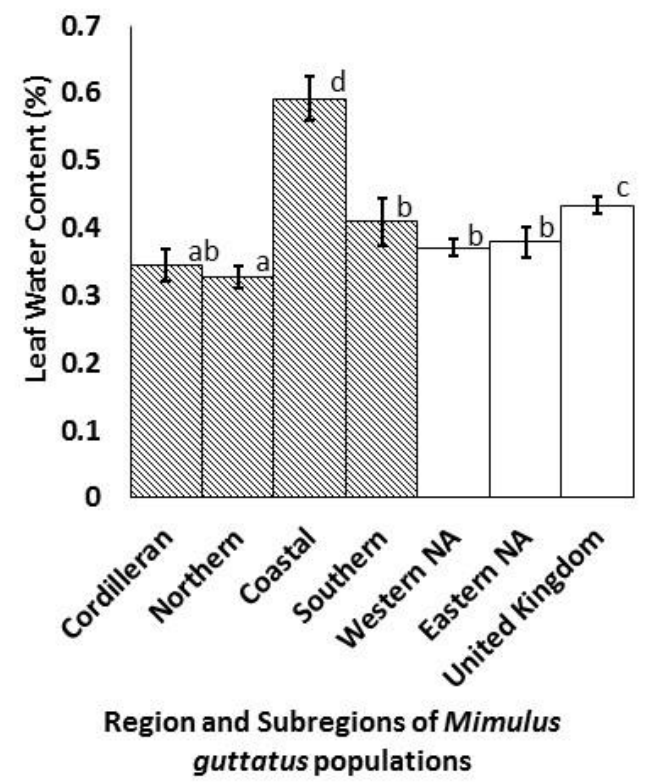

B.

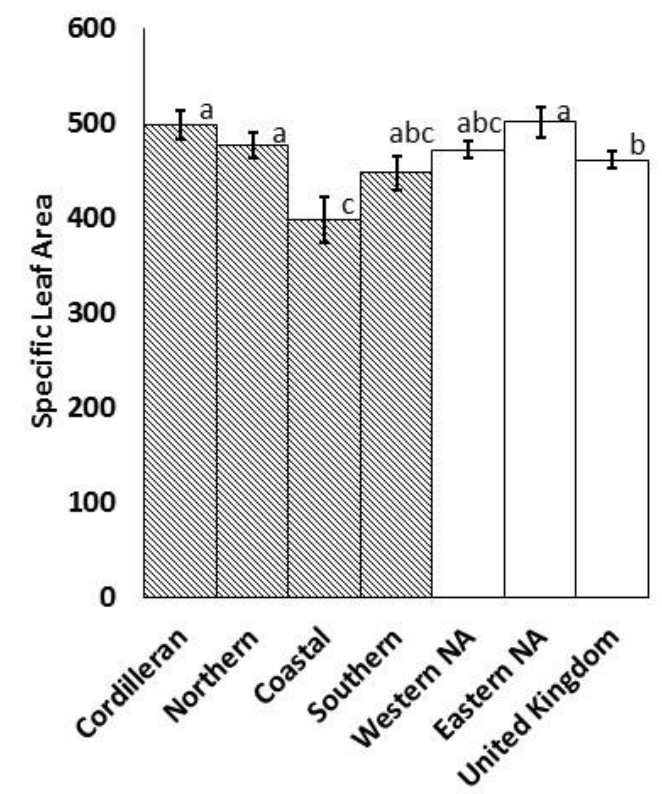

D.

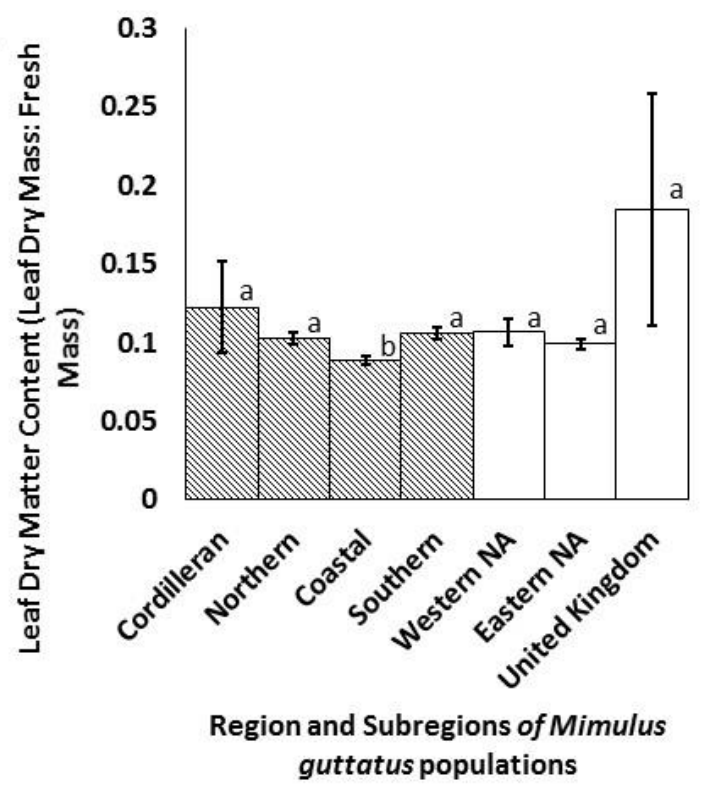

Figure 4. Average physical resistance traits (A. Trichomes, B. Specific Leaf Area, C. Water Content, D. HSD post-hoc test. Non-transformed data displayed. 

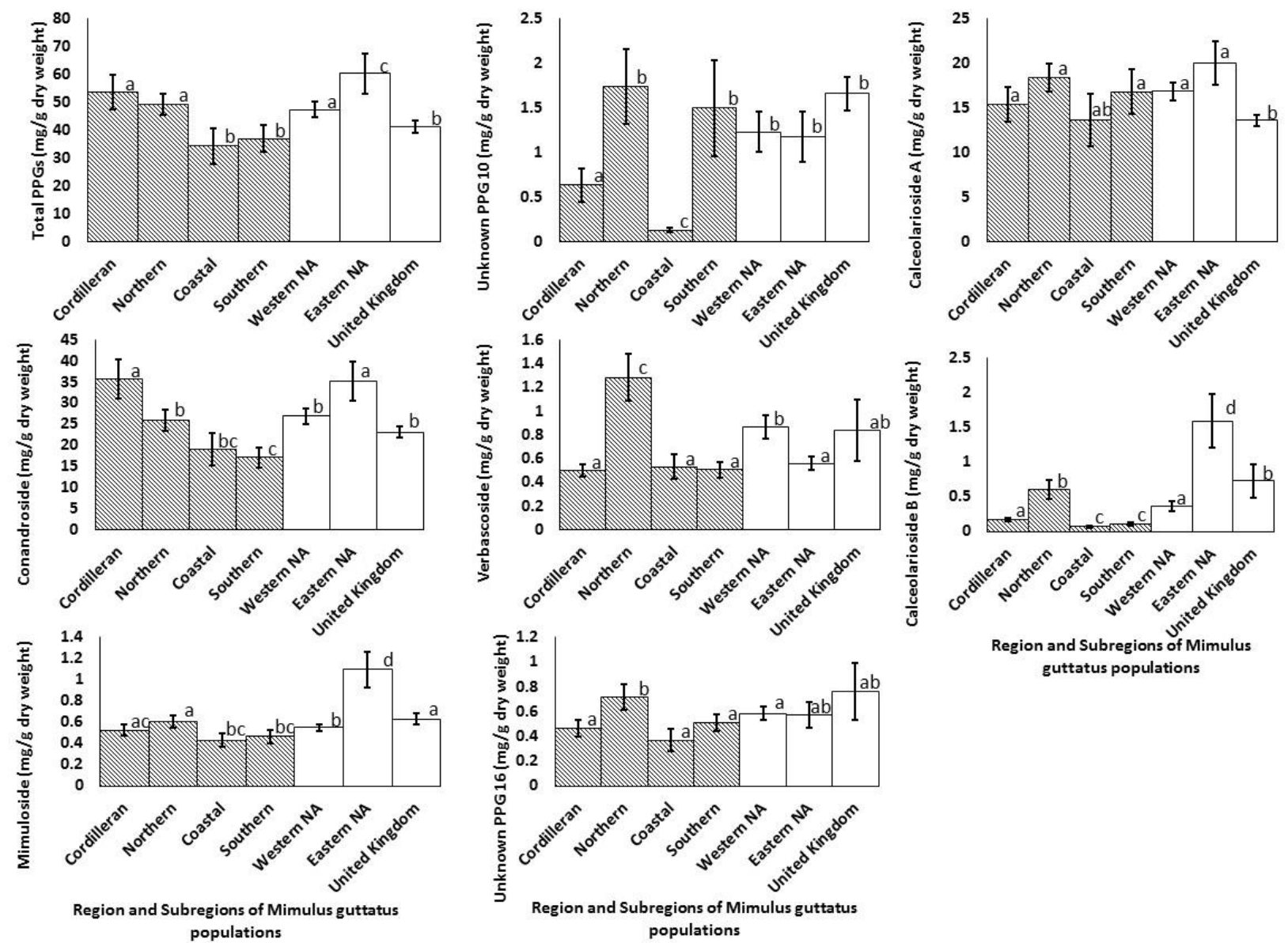

Figure 5. Average concentration (mg/ dry weight) of foliar phenylpropanoid glycosides within regions (white) and subregions (patterned) of M. guttatus populations. Error bars represent one standard error. Error bars represent \pm 1 standard error. Letters indicate equivalent values based on a Tukey HSD post-hoc test. Non-transformed data displayed. 


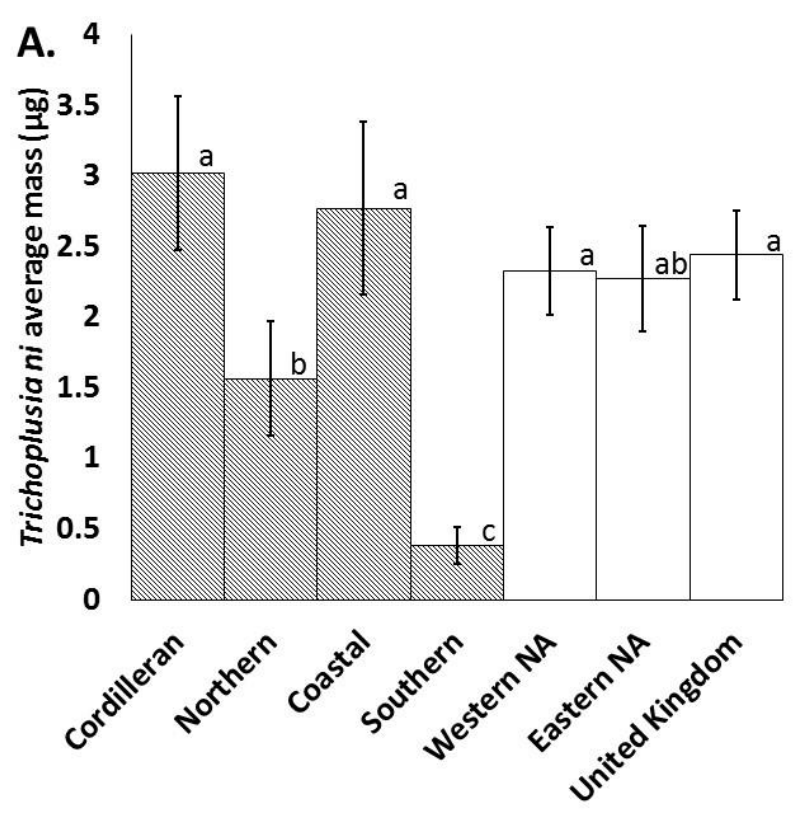

Regions and Subregion of Mimulus guttatus populations
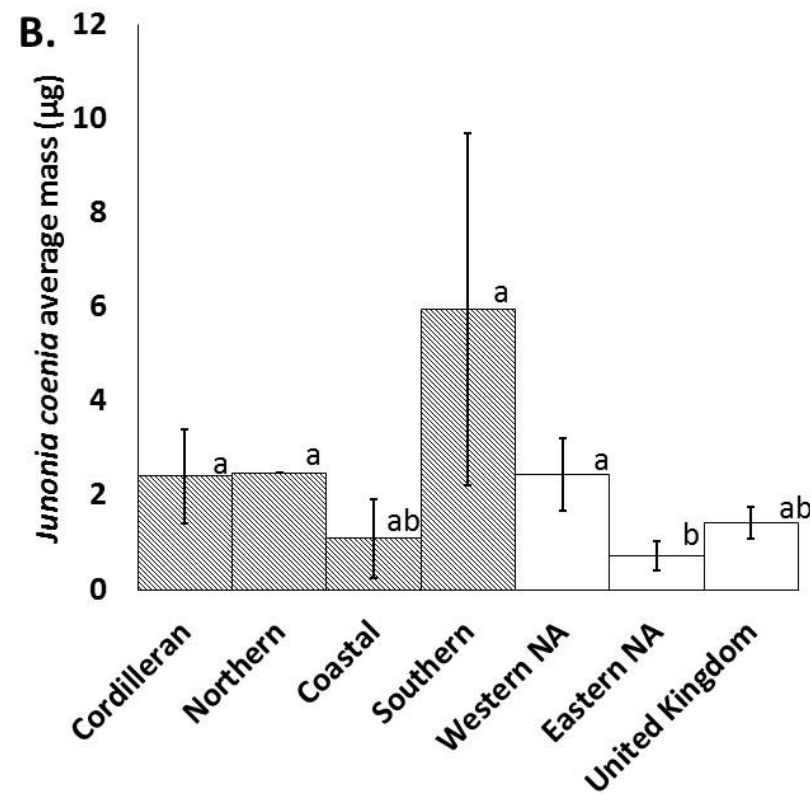

Regions and Subregion of Mimulus guttatus populations

Figure 6. Average performance (mass $\mu \mathrm{g}$ ) of (A.) the generalist caterpillar Trichoplusia ni and (B.) the specialist caterpillar Junonia coenia within regions (white) and subregions (patterned) of M. guttatus populations. Error bars represent \pm 1 standard error. Letters indicate equivalent values based on a Tukey HSD post-hoc test. Non-transformed data displayed. 

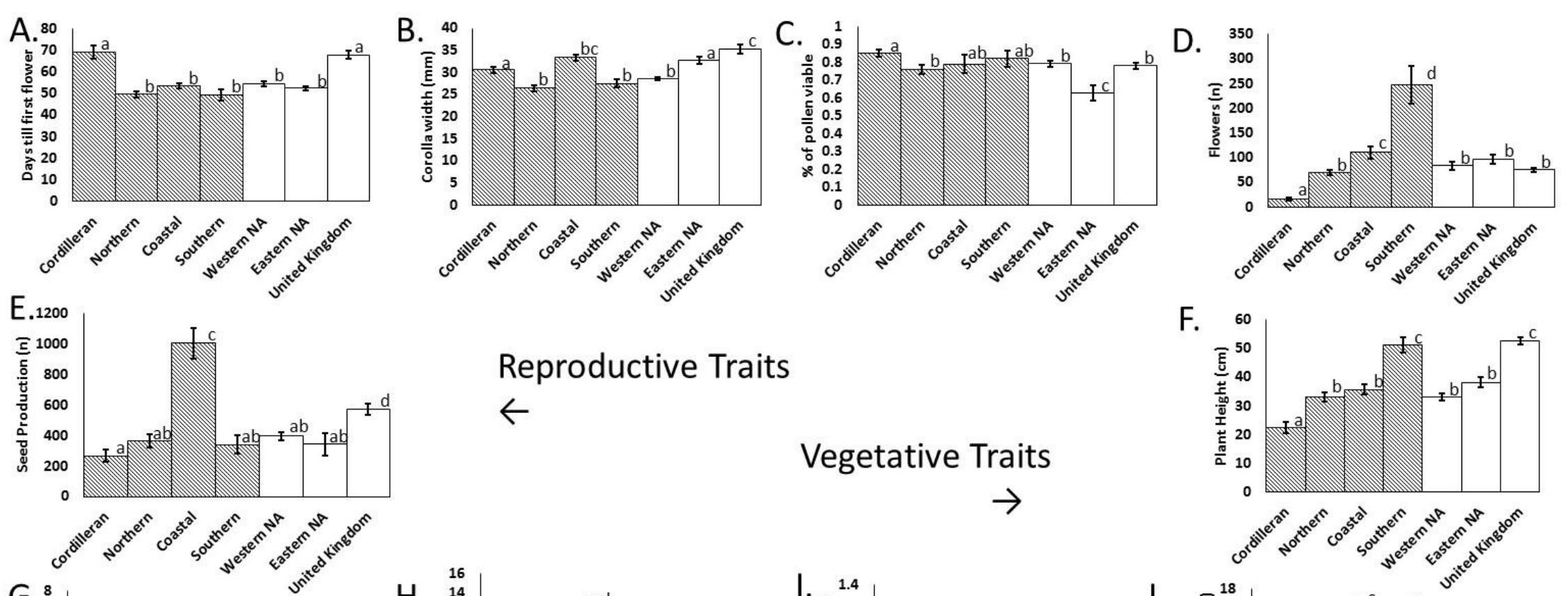

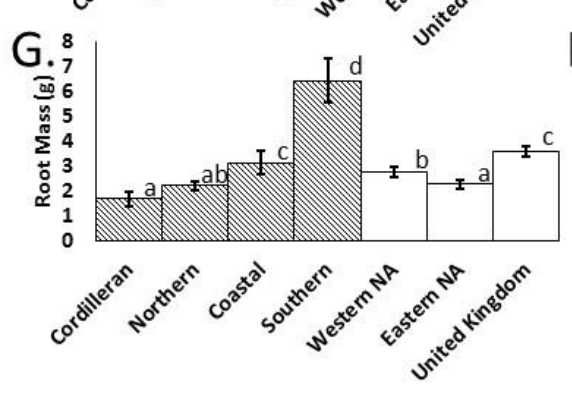

Region and Subregions of Mimulus guttatus populations

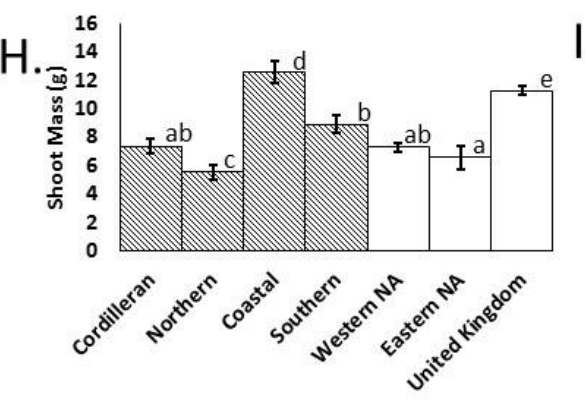

Region and Subregions of Mimulus guttatus populations

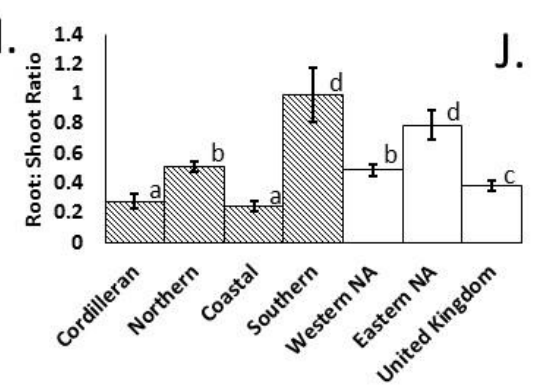

Region and Subregions of Mimulus guttatus populations
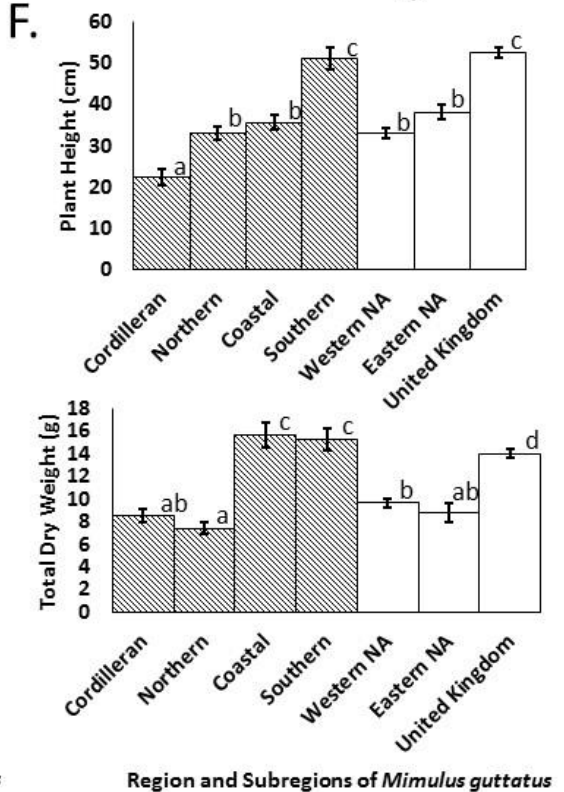
populations

Figure 7. Averages of measures of fitness / competitive ability traits. Reproductive traits: A. Number of days till first flower, B. Width of first corolla, C. Percent of pollen that is viable, D. Total number of flowers produced, E. Number of seeds from first three flowers. Vegetative traits: F. Plant height, G. Root dry mass, H. Shoot dry mass, I. Root:shoot ratio, J. Total dry biomass for Mimulus guttatus populations between regions (in white) and native subregions (patterned). Error bars represent \pm 1 standard error. Letters indicate equivalent values based on a Tukey HSD posthoc test. Non-transformed data displayed. 

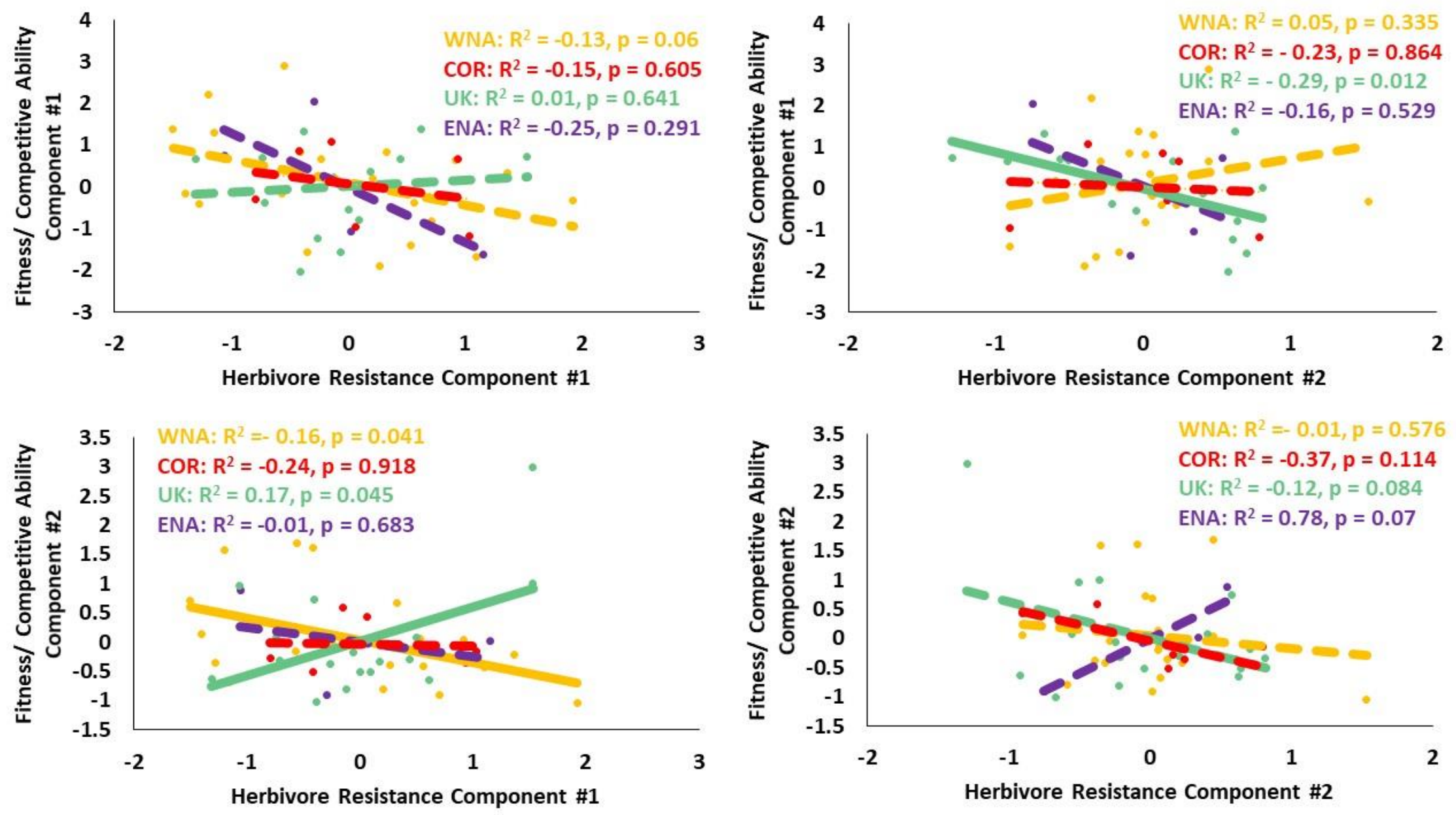

Figure 8. Regressions between fitness/ competitive traits PCA components and herbivore resistance trait PCA components of population means. WNA plants in Orange, Cordilleran plants (COR) in red, UK plants in teal and Eastern North American plants in green. Significant trend lines shown as solid with insignificant trend lines dotted. 


\section{Tables.}

Table 1. MRPP results for differences between the non-native regions and the native sub-regions herbivore community at the family level (on bottom and in grey) and functional feeding group (on top in white). The full model was significant for herbivore communities at the family level $(A=0.085, \mathrm{p}<$ $0.001)$ and for functional feeding groups $(\mathrm{A}=0.131, \mathrm{p}<0.001)$. Bolded results are significantly different pair wise comparisons.

\begin{tabular}{|c|c|c|c|c|c|c|}
\hline & Coastal & Cordilleran & Eastern NA & Northern & Southern & $\begin{array}{l}\text { United } \\
\text { Kingdom }\end{array}$ \\
\hline Coastal & & $\begin{array}{l}A=0.083 \\
p=0.082\end{array}$ & $\begin{array}{l}A=-0.063 \\
p=0.817\end{array}$ & $\begin{array}{l}A=-0.062 \\
p=0.894\end{array}$ & $\begin{array}{l}A=-0.069 \\
p=0.081\end{array}$ & $\begin{array}{l}A=- \\
0.029 \\
p=0.884\end{array}$ \\
\hline Cordilleran & $\begin{array}{l}A=0.020 \\
p=0.332\end{array}$ & & $\begin{array}{l}A=0.154 \\
p=0.019\end{array}$ & $\begin{array}{l}\mathrm{A}=0.292 \\
\mathrm{p}<0.001\end{array}$ & $\begin{array}{l}\mathbf{A}=\mathbf{0 . 1 7 7} \\
\mathbf{p}=\mathbf{0 . 0 0 8}\end{array}$ & $\begin{array}{l}A=0.131 \\
p<0.001\end{array}$ \\
\hline $\begin{array}{l}\text { Eastern } \\
\text { NA }\end{array}$ & $\begin{array}{l}A=-0.078 \\
p=0.908\end{array}$ & $\begin{array}{l}A=0.128 \\
p=0.0149\end{array}$ & & $\begin{array}{l}A=0.066 \\
p=0.066\end{array}$ & $\begin{array}{l}A=-0.031 \\
p=0.625\end{array}$ & $\begin{array}{l}A=0.014 \\
p=0.228\end{array}$ \\
\hline Northern & $\begin{array}{l}A=-0.042 \\
p=0.890\end{array}$ & $\begin{array}{l}\mathbf{A}=\mathbf{0 . 1 8 1} \\
\mathbf{p}<\mathbf{0 . 0 0 1}\end{array}$ & $\begin{array}{l}A=0.067 \\
p=0.028\end{array}$ & & $\begin{array}{l}A=-0.026 \\
p=0.680\end{array}$ & $\begin{array}{l}A=0.126 \\
p<0.001\end{array}$ \\
\hline Southern & $\begin{array}{l}A=-0.053 \\
p=0.812\end{array}$ & $\begin{array}{l}A=0.126 \\
p=0.019\end{array}$ & $\begin{array}{l}A=0.005 \\
p=0.433\end{array}$ & $\begin{array}{l}A=0.025 \\
p=0.215\end{array}$ & & $\begin{array}{l}A=0.039 \\
p=0.072\end{array}$ \\
\hline $\begin{array}{l}\text { United } \\
\text { Kingdom }\end{array}$ & $\begin{array}{l}A=-0.038 \\
p=0.998\end{array}$ & $\begin{array}{l}A=0.092 \\
p<0.001\end{array}$ & $\begin{array}{l}A=-0.017 \\
p=0.866\end{array}$ & $\begin{array}{l}A=0.099 \\
p<0.001\end{array}$ & $\begin{array}{l}A=0.028 \\
p=0.062\end{array}$ & \\
\hline
\end{tabular}


Table 2. Regression tradeoff results of fitness/ competitive ability PCA components vs herbivore resistance traits PCA components of population means. Significant results are in bold. PCA components are different for each of the regions, and are listed in the text.

\begin{tabular}{|l|l|l|}
\hline & Herbivore Resistance Component \#1 & Herbivore Resistance Component \#2 \\
\hline Fitness/ Competitive & WNA: $\mathbf{R}^{2}=0.13, p=0.06, \beta=-0.42$ & WNA: $\mathbf{R}^{2}=0.05, p=0.335, \beta=0.22$ \\
Ability Component \#1 & COR: $\mathbf{R}^{2}=0.15, p=0.605, \beta=-0.26$ & COR: $\mathbf{R}^{2}=0.23, p=0.864, \beta=-0.09$ \\
& UK: $\mathbf{R}^{2}=0.01, p=0.641, \beta=0.11$ & UK: $\mathbf{R}^{2}=\mathbf{0 . 2 9}, \mathbf{p}=\mathbf{0 . 0 1 2}, \beta=-0.57$ \\
& ENA: $\mathbf{R}^{2}=0.25, p=0.291, \beta=-0.71$ & ENA: $\mathbf{R}^{2}=0.16, p=0.529, \beta=-0.47$ \\
\hline Fitness/ Competitive & WNA: $\mathbf{R}^{2}=\mathbf{0 . 1 6}, \mathbf{p}=\mathbf{0 . 0 4 1}, \beta=-0.45$ & WNA: $\mathbf{R}^{2}=0.01, p=0.576, \beta=-0.13$ \\
Ability Component \#2 & COR: $\mathbf{R}^{2}=0.24, p=0.918, \beta=-0.05$ & COR: $\mathbf{R}^{2}=0.37, p=0.114, \beta=-0.71$ \\
& UK: $\mathbf{R}^{2}=\mathbf{0 . 1 7}, \mathbf{p}=\mathbf{0 . 0 4 5}, \beta=-0.57$ & UK: $\mathbf{R}^{2}=0.12, p=0.084, \beta=-0.42$ \\
& ENA: $\mathbf{R}^{2}=0.01, p=0.683, \beta=-0.47$ & ENA: $\mathbf{R}^{2}=0.78, p=0.07, \beta=0.92$ \\
\hline
\end{tabular}

Table 3. Comparisons between the two non-native ranges (United Kingdom, and eastern North America) and how they aligned with the predictions of evolution of increased competitive ability (EICA). United 
Kingdom plants are compaired against the native cordilleran subregion and the eastern North America plants are compared against the overall native western North American range.

\begin{tabular}{|c|c|c|c|}
\hline $\begin{array}{l}\text { Non- } \\
\text { native } \\
\text { Region }\end{array}$ & $\begin{array}{l}\text { Support of EICA } \\
\text { Predictions }\end{array}$ & Neutral to EICA predictions & $\begin{array}{l}\text { Contrary to EICA } \\
\text { Predictions }\end{array}$ \\
\hline $\begin{array}{l}\text { United } \\
\text { Kingdom }\end{array}$ & 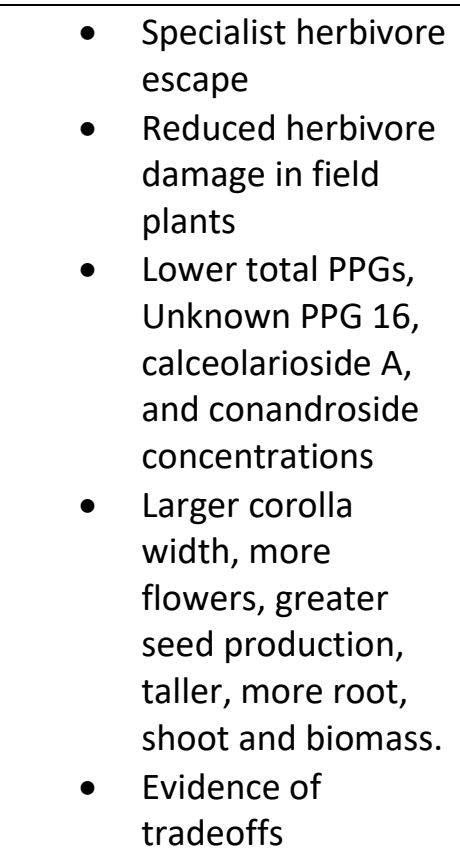 & $\begin{aligned} & \text { - Equivalent Traits: } \\
& \circ \quad \text { Specific leaf area } \\
& \circ \quad \text { Leaf dry matter } \\
& \text { content } \\
& \circ \text { Calceolarioside B } \\
& \text { and mimuloside } \\
& \circ \text { Specialist and } \\
& \text { generalist } \\
& \text { herbivore } \\
& \text { performance } \\
& \circ \quad \text { Days till flower } \\
&\end{aligned}$ & $\begin{array}{l}\text { - Higher average } \\
\text { trichome } \\
\text { density } \\
\text { - } \text { Greater leaf } \\
\text { water content } \\
\text { - Poorer pollen } \\
\text { viability }\end{array}$ \\
\hline $\begin{array}{l}\text { Eastern } \\
\text { North } \\
\text { America }\end{array}$ & $\begin{array}{ll} & \text { Lower average } \\
\text { trichome density } \\
\text { - } & \text { Lower verbascoside } \\
\text { concentration } \\
\text { - } & \text { Larger corolla } \\
\text { width, taller }\end{array}$ & $\begin{array}{cl}\text { - } & \text { Potential escape from } \\
\text { specialist herbivores } \\
\text { Equivalent Traits: } \\
\circ & \text { herbivore damage } \\
& \text { in field plants } \\
\circ & \text { specific leaf area } \\
\circ & \text { leaf water content } \\
\circ & \text { leaf dry matter } \\
& \text { content } \\
\circ & \text { Unknown PPG 10 } \\
\circ & \text { Calceolarioside A } \\
\circ & \text { Unknown PPG 16 } \\
\circ & \text { Specialist and } \\
& \text { generalist } \\
& \text { herbivore } \\
& \text { performance } \\
\circ & \text { Days till flower } \\
\circ & \text { Glower production } \\
\circ & \text { Seed production } \\
\circ & \text { Root, shoot and } \\
& \text { total biomass }\end{array}$ & $\begin{array}{l}\text { Higher } \\
\text { concentration } \\
\text { of Total PPGs, } \\
\text { conandroside, } \\
\text { calceolarioside } \\
\text { B, and } \\
\text { mimuloside } \\
\text { - Poorer pollen } \\
\text { viability } \\
\text { No evidence of } \\
\text { tradeoffs }\end{array}$ \\
\hline
\end{tabular}

\section{Supplemental Information}


Table S1. Locations of all populations used in this study. Name of population is population name in the monkeyflower seed library and the number of individuals used in the common garden for trait measurments. Plant life history, region and subregion based on field observation and literature (Stace 2010, Twyford and Freidman 2015).

\begin{tabular}{|c|c|c|c|c|c|}
\hline Population Name (n) & $\begin{array}{l}\text { Annual/ } \\
\text { Perennial/ } \\
\text { Facultative }\end{array}$ & Region & Subregion & $\begin{array}{l}\text { State/Province/ } \\
\text { Nation, Country }\end{array}$ & Coordinates \\
\hline Anchor River (13) & Perennial & $\begin{array}{l}\text { Western } \\
\text { North } \\
\text { America }\end{array}$ & Cordilleran & Alaska, USA & $\begin{array}{l}\text { N 59॰ } 44.468^{\prime}, \\
\text { W } 151^{\circ} 44.850^{\prime}\end{array}$ \\
\hline Bird Point Creek (12) & Perennial & $\begin{array}{l}\text { Western } \\
\text { North } \\
\text { America }\end{array}$ & Cordilleran & Alaska, USA & $\begin{array}{l}\text { N } 60^{\circ} 57.147^{\prime}, \\
\text { W } 149^{\circ} 24.673\end{array}$ \\
\hline Crooked Creek (9) & Perennial & $\begin{array}{l}\text { Western } \\
\text { North } \\
\text { America }\end{array}$ & Cordilleran & Alaska, USA & $\begin{array}{l}\text { N 61 08.295', } \\
\text { W } 146^{\circ} 19.479\end{array}$ \\
\hline $\begin{array}{l}\text { South Deep Creek } \\
\text { (13) }\end{array}$ & Perennial & $\begin{array}{l}\text { Western } \\
\text { North } \\
\text { America }\end{array}$ & Cordilleran & Alaska, USA & $\begin{array}{l}\text { N 60 01.744', } \\
\text { W } 151^{\circ} 40.988^{\prime}\end{array}$ \\
\hline Lowell Creek (13) & Perennial & $\begin{array}{l}\text { Western } \\
\text { North } \\
\text { America }\end{array}$ & Cordilleran & Alaska, USA & $\begin{array}{l}\text { N 60 06.078', } \\
\text { W } 149^{\circ} 27.704\end{array}$ \\
\hline TSG (13) & Perennial & $\begin{array}{l}\text { Western } \\
\text { North } \\
\text { America }\end{array}$ & Cordilleran & $\begin{array}{l}\text { British } \\
\text { Columbia, } \\
\text { Canada } \\
\end{array}$ & $\begin{array}{l}\text { N 53 } 41.888^{\prime}, \\
\text { W } 131^{\circ} 91.573\end{array}$ \\
\hline Harris Creek (12) & Facultative & $\begin{array}{l}\text { Western } \\
\text { North } \\
\text { America }\end{array}$ & Northern & Idaho, USA & $\begin{array}{l}\text { N 43 51.966', } \\
\text { W } 116^{\circ} 08.882^{\prime}\end{array}$ \\
\hline Nowhere Ditch (12) & Perennial & $\begin{array}{l}\text { Western } \\
\text { North } \\
\text { America }\end{array}$ & Northern & $\begin{array}{l}\text { Washington, } \\
\text { USA }\end{array}$ & $\begin{array}{l}\text { N } 46^{\circ} 77.261^{\prime}, \\
\text { W } 117^{\circ} 57.776^{\prime}\end{array}$ \\
\hline Cultus River (13) & Facultative & $\begin{array}{l}\text { Western } \\
\text { North } \\
\text { America }\end{array}$ & Northern & Oregon, USA & $\begin{array}{l}\text { N 43 } 49.337^{\prime}, \\
\text { W } 121^{\circ} 47.845^{\prime}\end{array}$ \\
\hline $\begin{array}{l}\text { North Fork Quinault } \\
\text { River (14) }\end{array}$ & Facultative & $\begin{array}{l}\text { Western } \\
\text { North } \\
\text { America }\end{array}$ & Northern & $\begin{array}{l}\text { Washington, } \\
\text { USA }\end{array}$ & $\begin{array}{l}\text { N 473 34.201', } \\
\text { W } 123^{\circ} 39.033^{\prime}\end{array}$ \\
\hline K. Moon Seep (13) & Annual & $\begin{array}{l}\text { Western } \\
\text { North } \\
\text { America }\end{array}$ & Northern & Wyoming, USA & $\begin{array}{l}\text { N 41 } 20.517^{\circ}, \\
\text { W } 110^{\circ} 54.714^{\prime}\end{array}$ \\
\hline $\begin{array}{l}\text { Thanks Amanda } \\
\text { Ditch (12) }\end{array}$ & Annual & $\begin{array}{l}\text { Western } \\
\text { North } \\
\text { America }\end{array}$ & Northern & Colorado, USA & $\begin{array}{l}\text { N 39 48.404', } \\
\text { W 107 } 35.370^{\circ}\end{array}$ \\
\hline $\begin{array}{l}\text { Lone Grave Spring } \\
\text { (15) }\end{array}$ & Annual & $\begin{array}{l}\text { Western } \\
\text { North } \\
\text { America }\end{array}$ & Northern & $\begin{array}{l}\text { South Dakota, } \\
\text { USA }\end{array}$ & $\begin{array}{l}\text { N 44 } 21.034^{\prime}, \\
\text { W 104 } 03.536^{\circ}\end{array}$ \\
\hline $\begin{array}{l}\text { Dispersed Camp } \\
\text { Spring (12) }\end{array}$ & Annual & $\begin{array}{l}\text { Western } \\
\text { North } \\
\text { America }\end{array}$ & Northern & Utah, USA & $\begin{array}{l}\text { N 40 37.684', } \\
\text { W } 111^{\circ} 10.719^{\prime}\end{array}$ \\
\hline
\end{tabular}




\begin{tabular}{|c|c|c|c|c|c|}
\hline $\begin{array}{l}\text { Heceta Head } \\
\text { Lighthouse (12) }\end{array}$ & Perennial & $\begin{array}{l}\text { Western } \\
\text { North } \\
\text { America }\end{array}$ & Coastal & Oregon, USA & $\begin{array}{l}\text { N 440 08.100', } \\
\text { W } 124^{\circ} 07.358^{\prime}\end{array}$ \\
\hline Population E (12) & Perennial & $\begin{array}{l}\text { Western } \\
\text { North } \\
\text { America }\end{array}$ & Coastal & California, USA & $\begin{array}{l}\text { N } 38^{\circ} 04.875^{\prime}, \\
\text { W } 122^{\circ} 08.696^{\prime}\end{array}$ \\
\hline Klamath Bog (12) & Perennial & $\begin{array}{l}\text { Western } \\
\text { North } \\
\text { America }\end{array}$ & Coastal & California, USA & 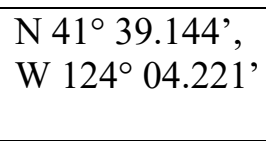 \\
\hline $\begin{array}{l}\text { Bagby Boat Launch } \\
\text { (9) }\end{array}$ & Annual & $\begin{array}{l}\text { Western } \\
\text { North } \\
\text { America }\end{array}$ & Southern & California, USA & $\begin{array}{l}\text { N 37 36.369', } \\
\text { W } 120^{\circ} 08.061^{\prime}\end{array}$ \\
\hline Kern Canyon (12) & Perennial & $\begin{array}{l}\text { Western } \\
\text { North } \\
\text { America }\end{array}$ & Southern & California, USA & $\begin{array}{l}\text { N 39 } 25.380^{\prime}, \\
\text { W } 115^{\circ} 03.845^{\prime}\end{array}$ \\
\hline $\begin{array}{l}\text { Dairy Farm Spring } \\
\text { (12) }\end{array}$ & Perennial & $\begin{array}{l}\text { Western } \\
\text { North } \\
\text { America }\end{array}$ & Southern & Arizona, USA & $\begin{array}{l}\text { N 34 09.458', } \\
\text { W } 111^{\circ} 48.192^{\prime}\end{array}$ \\
\hline Bass River (12) & Perennial & $\begin{array}{l}\text { Eastern } \\
\text { North } \\
\text { America }\end{array}$ & $\begin{array}{l}\text { Eastern } \\
\text { North } \\
\text { America }\end{array}$ & $\begin{array}{l}\text { New Brunswick, } \\
\text { Canada }\end{array}$ & $\begin{array}{l}\text { N 46 } 32.904^{\prime}, \\
\text { W 65 } 06.607^{\circ}\end{array}$ \\
\hline Springfield Ditch (12) & Perennial & $\begin{array}{l}\text { Eastern } \\
\text { North } \\
\text { America }\end{array}$ & $\begin{array}{l}\text { Eastern } \\
\text { North } \\
\text { America }\end{array}$ & $\begin{array}{l}\text { New Brunswick, } \\
\text { Canada }\end{array}$ & $\begin{array}{l}\text { N 46 } 41.476^{\prime}, \\
\text { W } 65^{\circ} 49.201\end{array}$ \\
\hline $\begin{array}{l}\text { Ontonagon Spring } \\
\text { (13) }\end{array}$ & Perennial & $\begin{array}{l}\text { Eastern } \\
\text { North } \\
\text { America }\end{array}$ & $\begin{array}{l}\text { Eastern } \\
\text { North } \\
\text { America }\end{array}$ & Michigan, USA & $\begin{array}{l}\text { Protected Plant } \\
\text { Species }\end{array}$ \\
\hline Fly Creek (12) & Perennial & $\begin{array}{l}\text { Eastern } \\
\text { North } \\
\text { America }\end{array}$ & $\begin{array}{l}\text { Eastern } \\
\text { North } \\
\text { America }\end{array}$ & New York, USA & $\begin{array}{l}\text { On Private } \\
\text { Property }\end{array}$ \\
\hline $\begin{array}{l}\text { John Muir Footpath } \\
\text { (13) }\end{array}$ & Perennial & $\begin{array}{l}\text { United } \\
\text { Kingdom }\end{array}$ & $\begin{array}{l}\text { United } \\
\text { Kingdom }\end{array}$ & $\begin{array}{l}\text { Scotland, United } \\
\text { Kingdom }\end{array}$ & $\begin{array}{l}\text { N 55 59.698', } \\
\text { W } 002^{\circ} 33.400^{\prime}\end{array}$ \\
\hline Balfron Mud Flat (13) & Perennial & $\begin{array}{l}\text { United } \\
\text { Kingdom }\end{array}$ & $\begin{array}{l}\text { United } \\
\text { Kingdom }\end{array}$ & $\begin{array}{l}\text { Scotland, United } \\
\text { Kingdom }\end{array}$ & $\begin{array}{l}\text { N 56 } 03.918^{\prime}, \\
\text { W } 004^{\circ} 23.453^{\prime}\end{array}$ \\
\hline Durness Stream (12) & Perennial & $\begin{array}{l}\text { United } \\
\text { Kingdom }\end{array}$ & $\begin{array}{l}\text { United } \\
\text { Kingdom }\end{array}$ & $\begin{array}{l}\text { Scotland, United } \\
\text { Kingdom }\end{array}$ & $\begin{array}{l}\text { N 58 34.031', } \\
\text { W 004 44.291', }\end{array}$ \\
\hline Loch Broom Hill (12) & Perennial & $\begin{array}{l}\text { United } \\
\text { Kingdom }\end{array}$ & $\begin{array}{l}\text { United } \\
\text { Kingdom }\end{array}$ & $\begin{array}{l}\text { Scotland, United } \\
\text { Kingdom }\end{array}$ & $\begin{array}{l}\text { N 57 } 49.738^{\circ}, \\
\text { W } 005^{\circ} 03.975^{\prime}\end{array}$ \\
\hline River Ness (12) & Perennial & $\begin{array}{l}\text { United } \\
\text { Kingdom }\end{array}$ & $\begin{array}{l}\text { United } \\
\text { Kingdom }\end{array}$ & $\begin{array}{l}\text { Scotland, United } \\
\text { Kingdom }\end{array}$ & $\begin{array}{l}\text { N 57 } 28.816^{\prime}, \\
\text { W 004 } 13.999^{\circ}\end{array}$ \\
\hline $\begin{array}{l}\text { Packhorse Bridge } \\
\text { (13) }\end{array}$ & Perennial & $\begin{array}{l}\text { United } \\
\text { Kingdom }\end{array}$ & $\begin{array}{l}\text { United } \\
\text { Kingdom }\end{array}$ & $\begin{array}{l}\text { Scotland, United } \\
\text { Kingdom }\end{array}$ & $\begin{array}{l}\text { N 57 } 21.159^{\prime}, \\
\text { W } 003^{\circ} 20.246^{\prime}\end{array}$ \\
\hline Dunblane River (9) & Perennial & $\begin{array}{l}\text { United } \\
\text { Kingdom }\end{array}$ & $\begin{array}{l}\text { United } \\
\text { Kingdom }\end{array}$ & $\begin{array}{l}\text { Scotland, United } \\
\text { Kingdom }\end{array}$ & $\begin{array}{l}\text { N 56 } 11.199^{\prime}, \\
\text { W } 003^{\circ} 57.872^{\prime}\end{array}$ \\
\hline $\begin{array}{l}\text { Deer Abby Creek } \\
\text { (14) }\end{array}$ & Perennial & $\begin{array}{l}\text { United } \\
\text { Kingdom }\end{array}$ & $\begin{array}{l}\text { United } \\
\text { Kingdom }\end{array}$ & $\begin{array}{l}\text { Scotland, United } \\
\text { Kingdom }\end{array}$ & $\begin{array}{l}\text { N 57 } 31.394^{\prime}, \\
\text { W } 002^{\circ} 03.482^{\prime}\end{array}$ \\
\hline West Park Farm (12) & Perennial & $\begin{array}{l}\text { United } \\
\text { Kingdom }\end{array}$ & $\begin{array}{l}\text { United } \\
\text { Kingdom }\end{array}$ & $\begin{array}{l}\text { Scotland, United } \\
\text { Kingdom }\end{array}$ & $\begin{array}{l}\text { N 56 } 18.097^{\circ}, \\
\text { W } 003^{\circ} 47.038^{\prime}\end{array}$ \\
\hline River Ayre Seep (13) & Perennial & $\begin{array}{l}\text { United } \\
\text { Kingdom }\end{array}$ & $\begin{array}{l}\text { United } \\
\text { Kingdom }\end{array}$ & $\begin{array}{l}\text { Scotland, United } \\
\text { Kingdom }\end{array}$ & $\begin{array}{l}\text { N 55 } 27.690^{\prime}, \\
\text { W 004 } 37.542^{\circ}\end{array}$ \\
\hline
\end{tabular}




\begin{tabular}{|c|c|c|c|c|c|}
\hline $\begin{array}{l}\text { River Nith Bridge } \\
\text { (12) }\end{array}$ & Perennial & $\begin{array}{l}\text { United } \\
\text { Kingdom }\end{array}$ & $\begin{array}{l}\text { United } \\
\text { Kingdom }\end{array}$ & $\begin{array}{l}\text { Scotland, United } \\
\text { Kingdom }\end{array}$ & 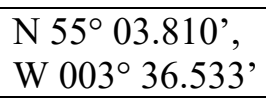 \\
\hline $\begin{array}{l}\text { St. Catherine Pasture } \\
\text { (12) }\end{array}$ & Perennial & $\begin{array}{l}\text { United } \\
\text { Kingdom }\end{array}$ & $\begin{array}{l}\text { United } \\
\text { Kingdom }\end{array}$ & $\begin{array}{l}\text { Wales, United } \\
\text { Kingdom }\end{array}$ & $\begin{array}{l}\text { N } 52^{\circ} 59.361^{\prime}, \\
\text { W } 003^{\circ} 27.960^{\prime}\end{array}$ \\
\hline $\begin{array}{l}\text { Cerria Condrudion } \\
\text { (12) }\end{array}$ & Perennial & $\begin{array}{l}\text { United } \\
\text { Kingdom }\end{array}$ & $\begin{array}{l}\text { United } \\
\text { Kingdom }\end{array}$ & $\begin{array}{l}\text { Wales, United } \\
\text { Kingdom }\end{array}$ & $\begin{array}{l}\text { N 530 } 00.345^{\prime}, \\
\text { W } 003^{\circ} 32.949^{\prime}\end{array}$ \\
\hline $\begin{array}{l}\text { Coldstream Bridge } \\
\text { (12) }\end{array}$ & Perennial & $\begin{array}{l}\text { United } \\
\text { Kingdom }\end{array}$ & $\begin{array}{l}\text { United } \\
\text { Kingdom }\end{array}$ & $\begin{array}{l}\text { England, United } \\
\text { Kingdom }\end{array}$ & $\begin{array}{l}\text { N 55 39.288', } \\
\text { W } 002^{\circ} 14.363\end{array}$ \\
\hline Exford Bridge (12) & Perennial & $\begin{array}{l}\text { United } \\
\text { Kingdom }\end{array}$ & $\begin{array}{l}\text { United } \\
\text { Kingdom }\end{array}$ & $\begin{array}{l}\text { England, United } \\
\text { Kingdom }\end{array}$ & $\begin{array}{l}\text { N 510 07.980', } \\
\text { W 003 } 38.506^{\circ}\end{array}$ \\
\hline Crowan Field (14) & Perennial & $\begin{array}{l}\text { United } \\
\text { Kingdom }\end{array}$ & $\begin{array}{l}\text { United } \\
\text { Kingdom }\end{array}$ & $\begin{array}{l}\text { England, United } \\
\text { Kingdom }\end{array}$ & $\begin{array}{l}\text { N 50 09.795', } \\
\text { W } 005^{\circ} 17.578^{\prime}\end{array}$ \\
\hline $\begin{array}{l}\text { Houghton Lodge } \\
\text { Stream (12) }\end{array}$ & Perennial & $\begin{array}{l}\text { United } \\
\text { Kingdom }\end{array}$ & $\begin{array}{l}\text { United } \\
\text { Kingdom }\end{array}$ & $\begin{array}{l}\text { England, United } \\
\text { Kingdom }\end{array}$ & $\begin{array}{l}\text { N 51 } 1^{\circ} 04.806^{\prime}, \\
\text { W } 001^{\circ} 31.009^{\prime}\end{array}$ \\
\hline $\begin{array}{l}\text { Brampton Stream and } \\
\text { Field (12) }\end{array}$ & Perennial & $\begin{array}{l}\text { United } \\
\text { Kingdom }\end{array}$ & $\begin{array}{l}\text { United } \\
\text { Kingdom }\end{array}$ & $\begin{array}{l}\text { England, United } \\
\text { Kingdom }\end{array}$ & $\begin{array}{l}\text { N 52 } 2^{\circ} 46.087^{\prime} \\
\text { E } 001^{\circ} 17.870^{\prime}\end{array}$ \\
\hline
\end{tabular}

WNA Correlation Matrix
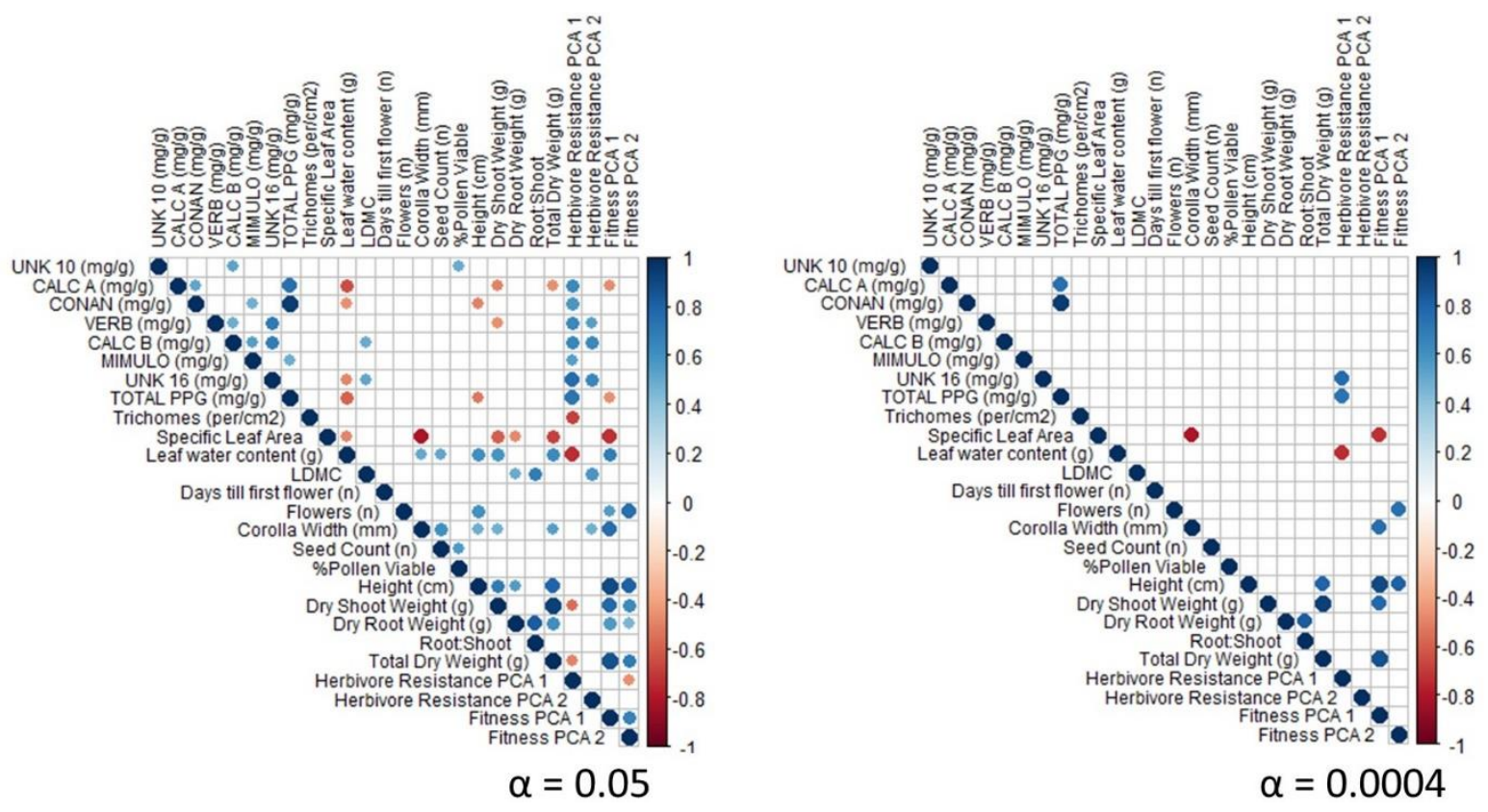
Figure S1. Correlation matrix for population means of all continuous pairwise traits measured for native western North America populations (WNA). Blue indicates a positive $r$ value and red being a negative $r$ value. Only significant $r$ values are displayed. Left figure is with $\alpha$ set at 0.05 and right figure is adjusted $\alpha$ of 0.0004 for multiple tests.

\section{UK Correlation Matrix}
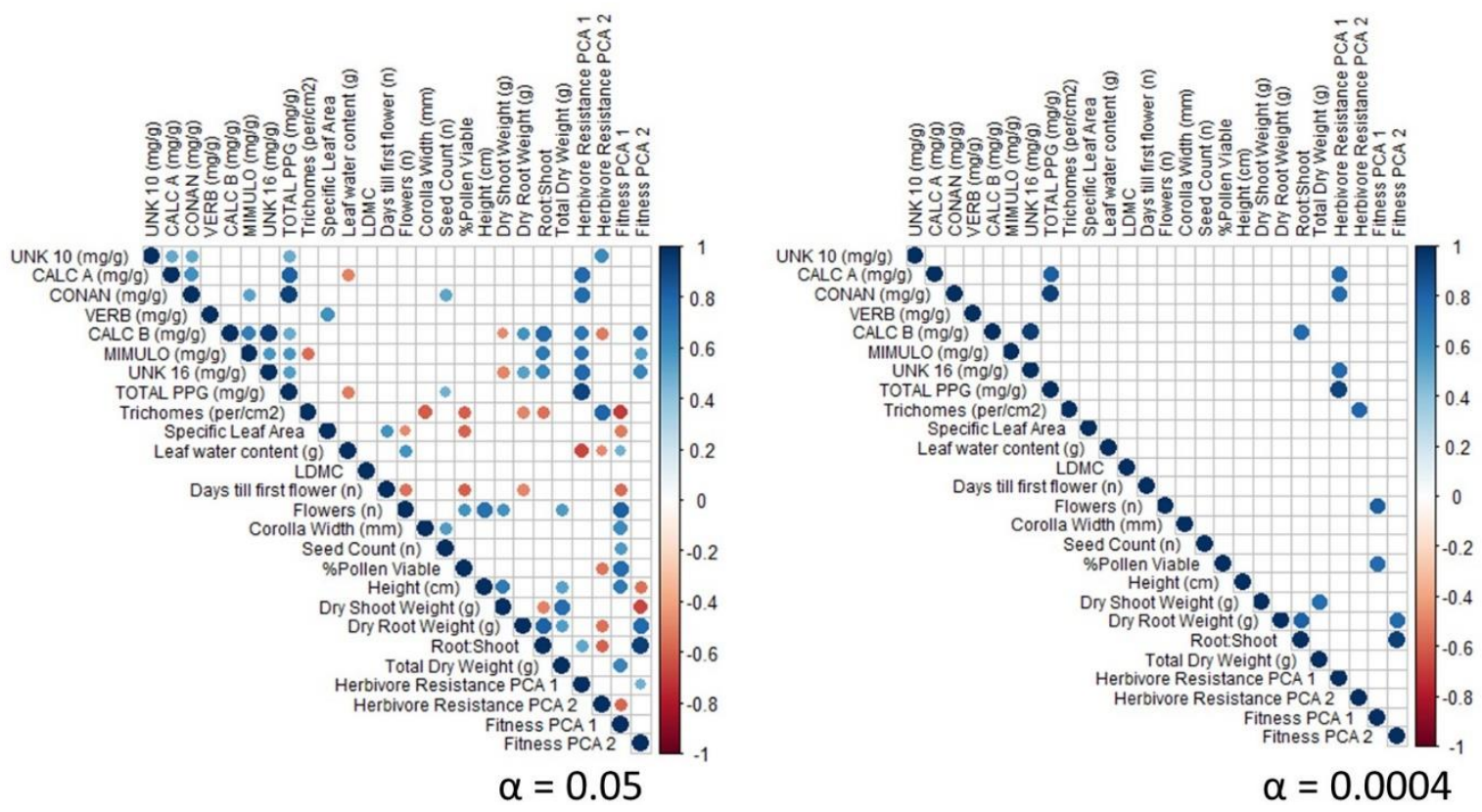

Figure S2. Correlation matrix for population means of all continuous pairwise traits measured for United Kingdom populations (UK). Blue indicates a positive $r$ value and red being a negative $r$ value. Only significant $r$ values are displayed. Left figure is with $\alpha$ set at 0.05 and right figure is adjusted $\alpha$ of 0.0004 for multiple tests. 


\section{ENA Correlation Matrix}
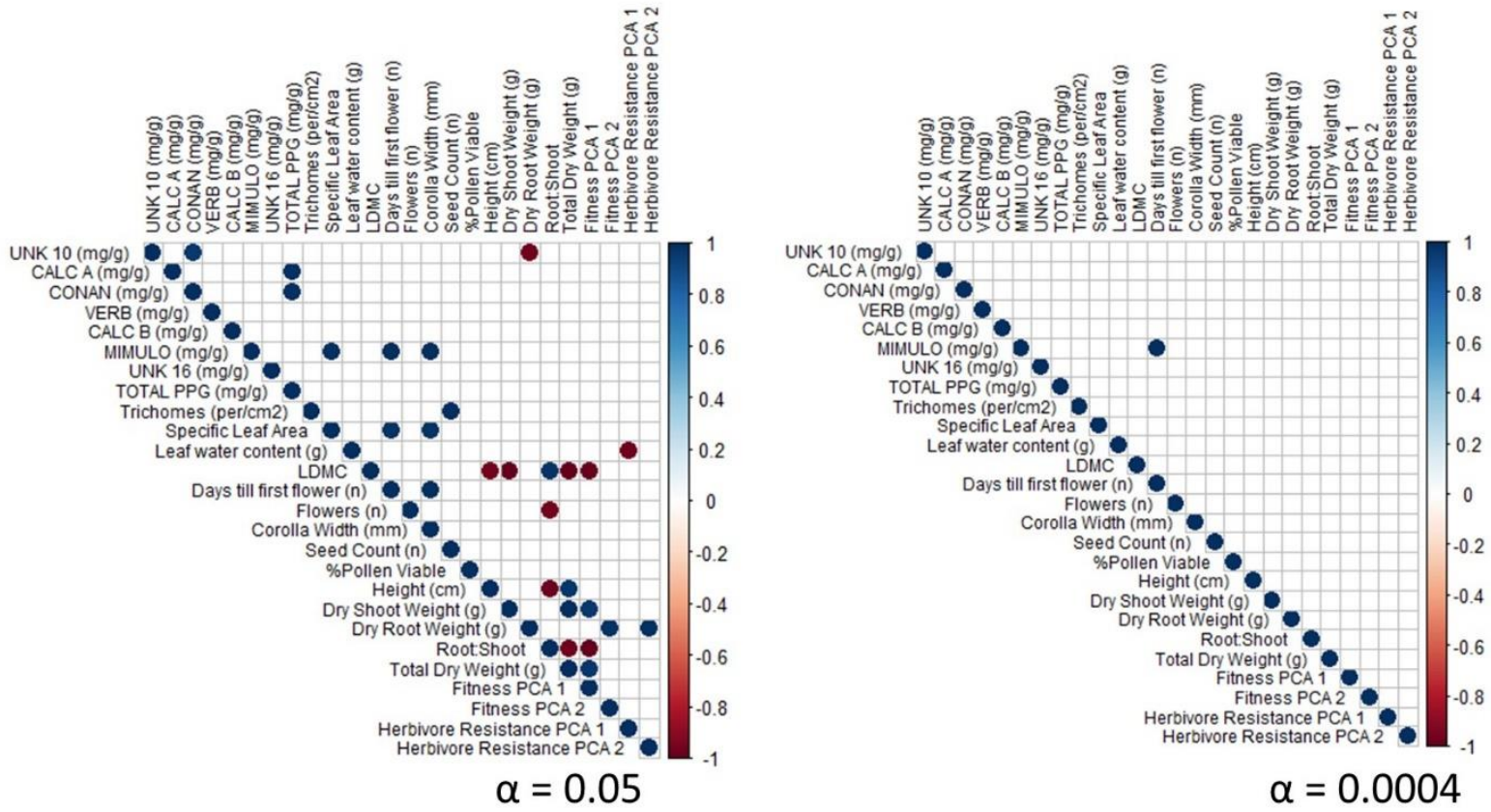

Figure S3. Correlation matrix for population means of all continuous pairwise traits measured for eastern North America populations (ENA). Blue indicates a positive $r$ value and red being a negative $r$ value. Only significant $r$ values are displayed. Left figure is with $\alpha$ set at 0.05 and right figure is adjusted $\alpha$ of 0.0004 for multiple tests. 


\section{Eastern North America Supplemental}

There is a lack of information on the origins in the eastern North American populations. These populations likely represent multiple introductions of varying different invasion routes with unknown origins. The following figures are presented with comparisons of averages from the individual eastern North American populations to native subregions. See Table S1 for population names and locations.
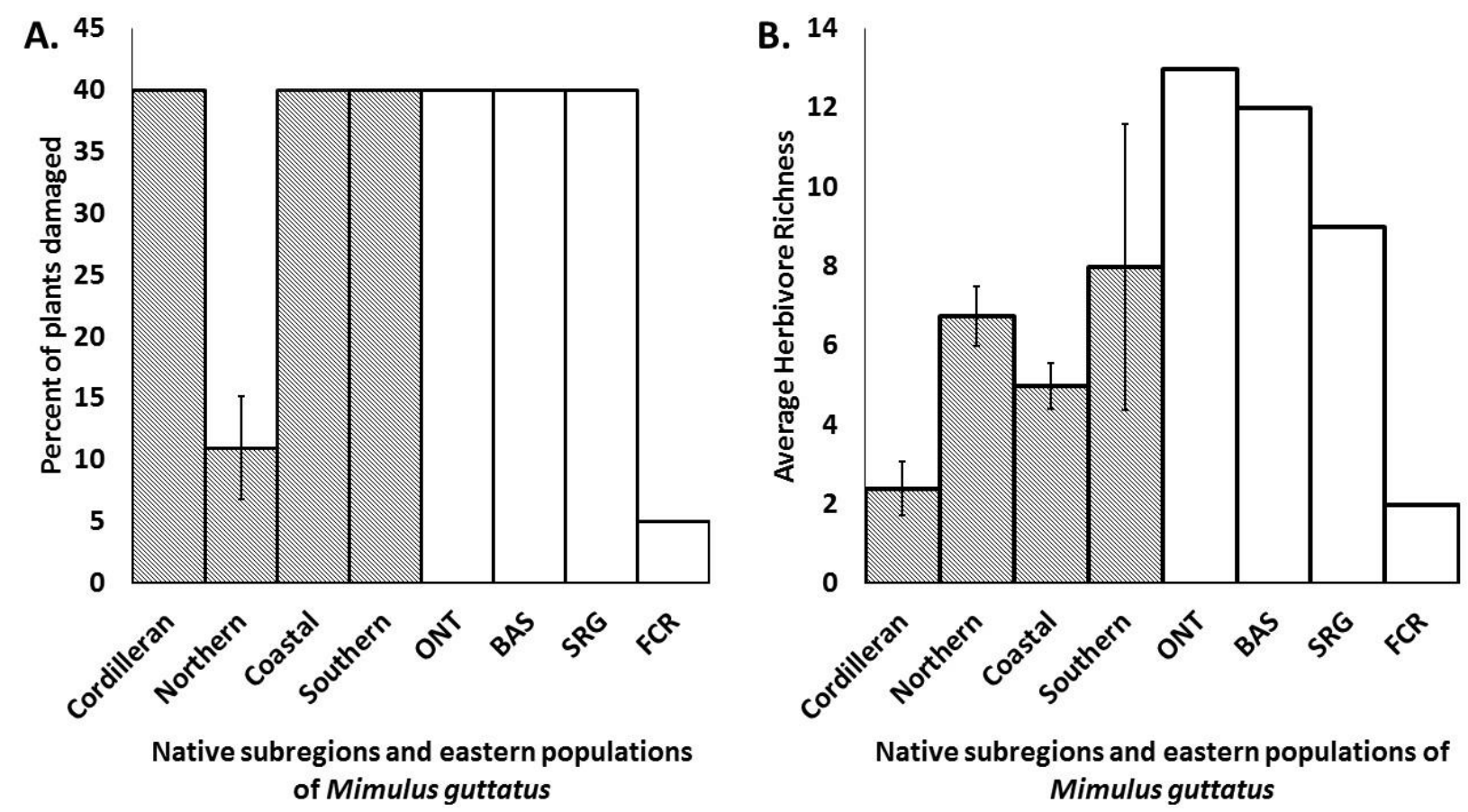

Native subregions and eastern populations of Mimulus guttatus

ENA S1. A. Percent of plants with herbivore damage in wild growing Mimulus guttatus populations between eastern North American populations (in white) and native subregions (patterned). B. Average herbivore species richness found in the field feeding on Mimulus guttatus populations between eastern North American populations (in white) and native subregions (patterned). Error bars represent \pm 1 standard error. Non-transformed data displayed. 

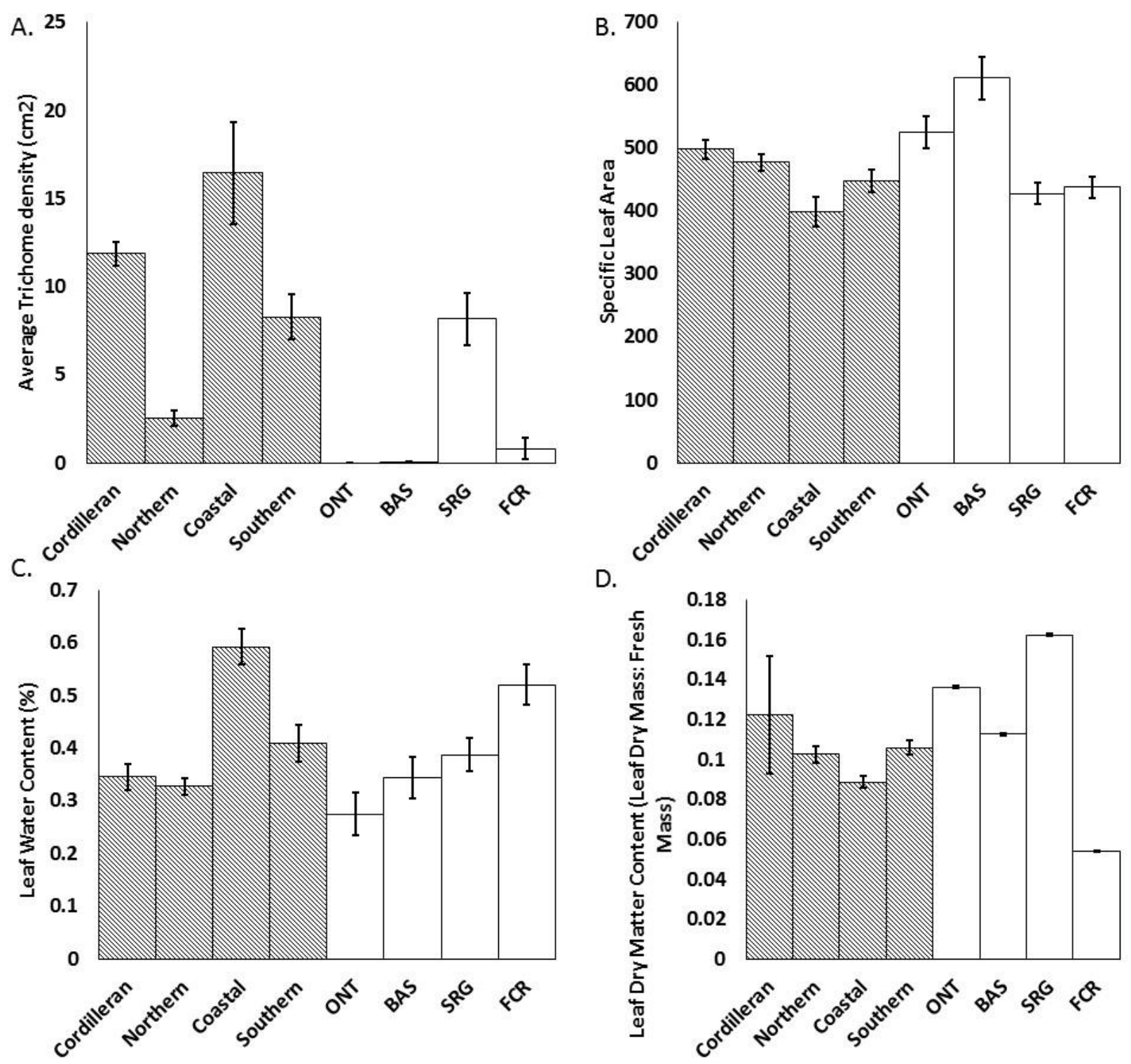

Subregions and eastern populations of Mimulus guttatus

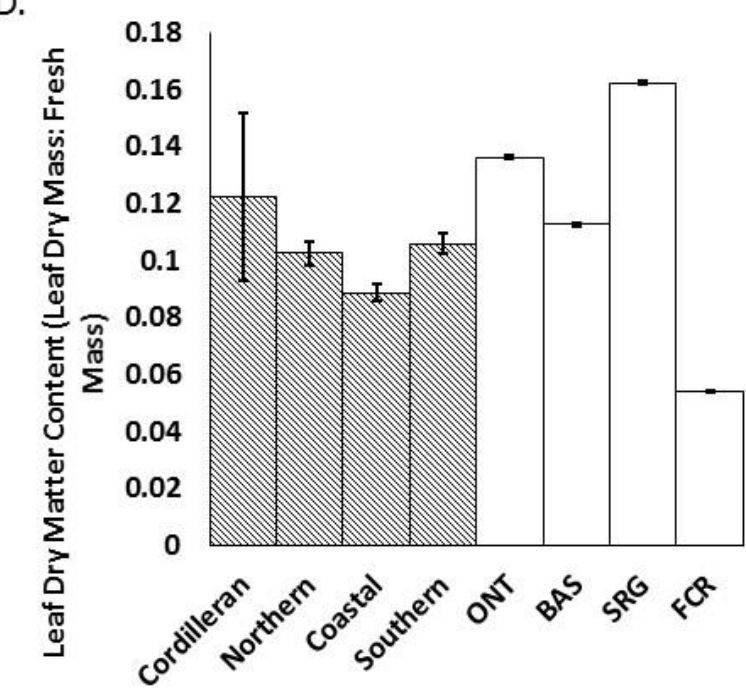

Subregions and eastern populations of Mimulus guttatus

ENA S2. Average physical resistance traits (A. Trichomes, B. Specific Leaf Area, C. Water Content, D. Dry Leaf Matter) in Mimulus guttatus populations between eastern North American populations (in white) and native subregions (patterned). Error bars represent \pm 1 standard error. Non-transformed data displayed. 

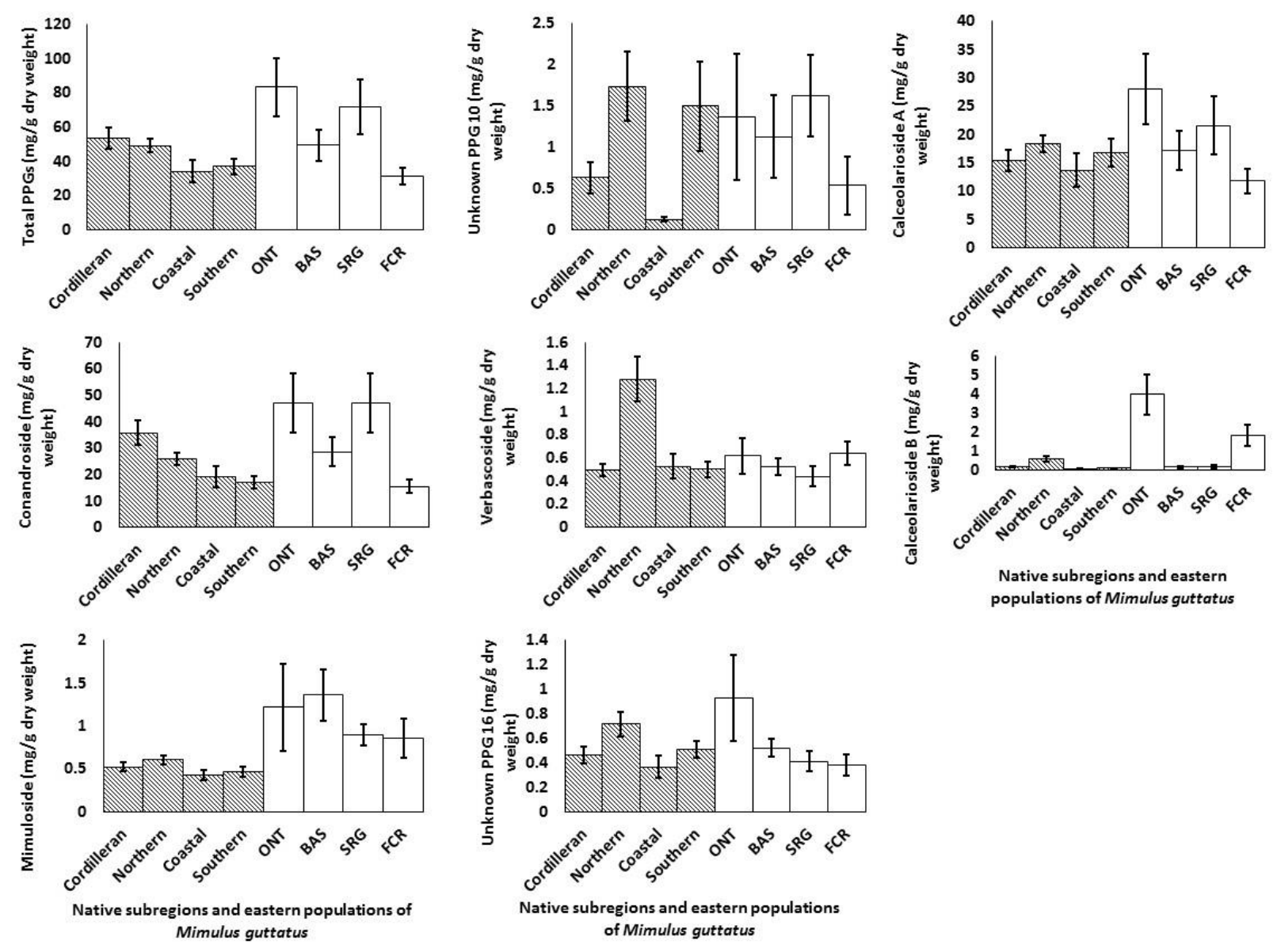

ENA S3. Average concentration (mg/ dry weight) of foliar phenylpropanoid glycosides within eastern North American populations (white) and subregions (patterned) of M. guttatus populations. Error bars represent one standard error. Error bars represent \pm 1 standard error. Non-transformed data displayed. 

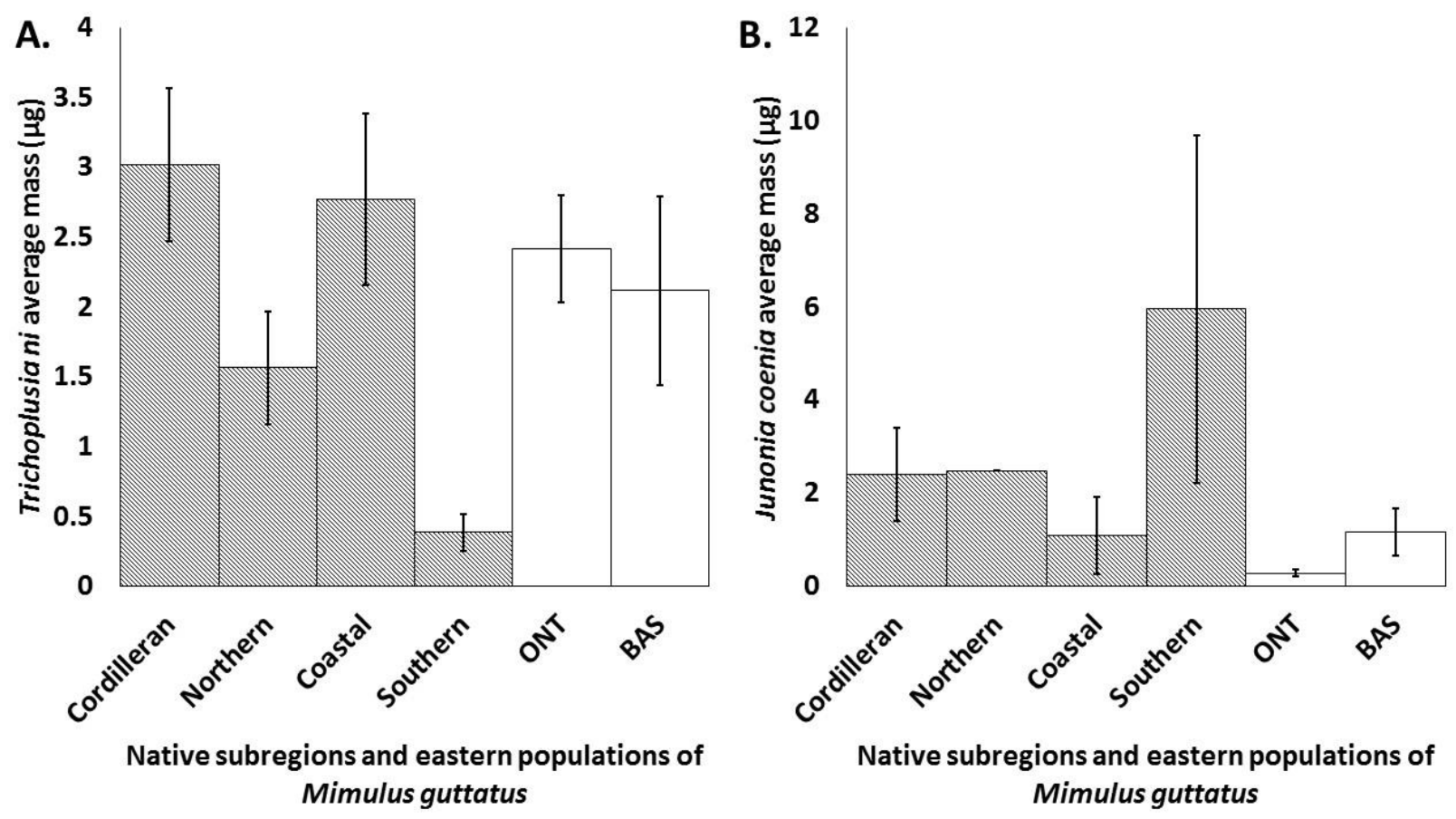

ENA S4. Average performance (mass $\mu \mathrm{g}$ ) of (A.) the generalist caterpillar Trichoplusia ni and (B.) the specialist caterpillar Junonia coenia within eastern North American populations (white) and subregions (patterned) of M. guttatus populations. Error bars represent \pm 1 standard error. Non-transformed data displayed 

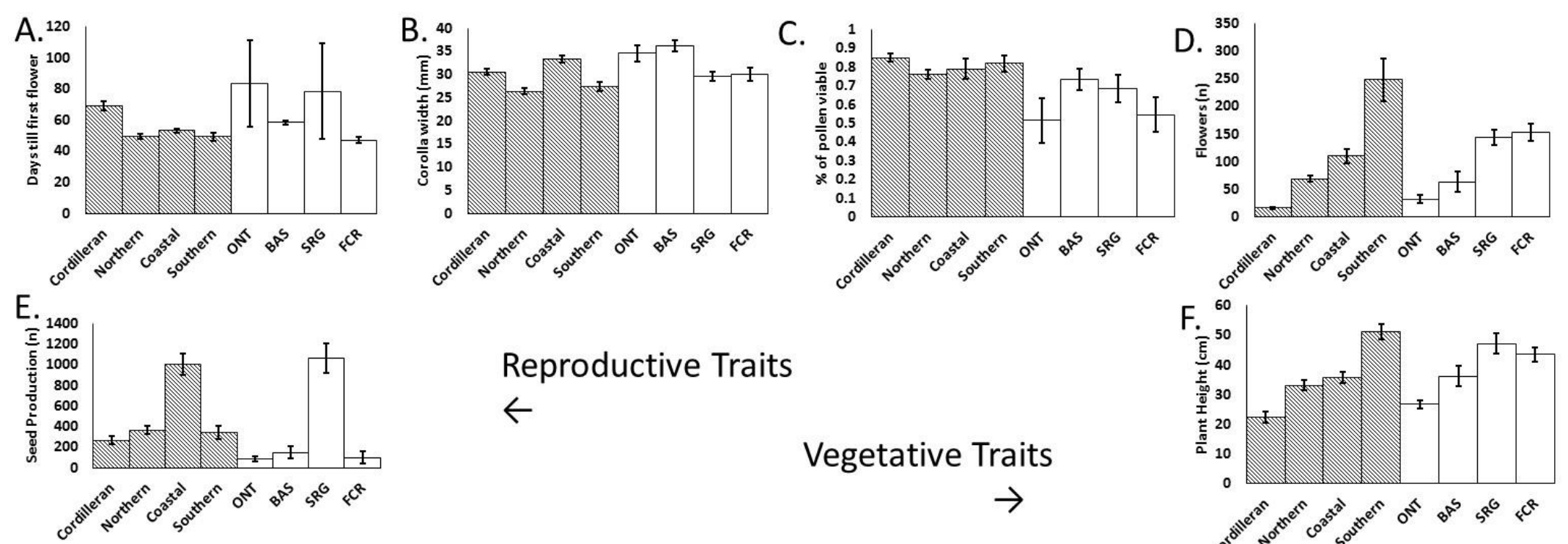

\section{Reproductive Traits}

$\leftarrow$

Vegetative Traits
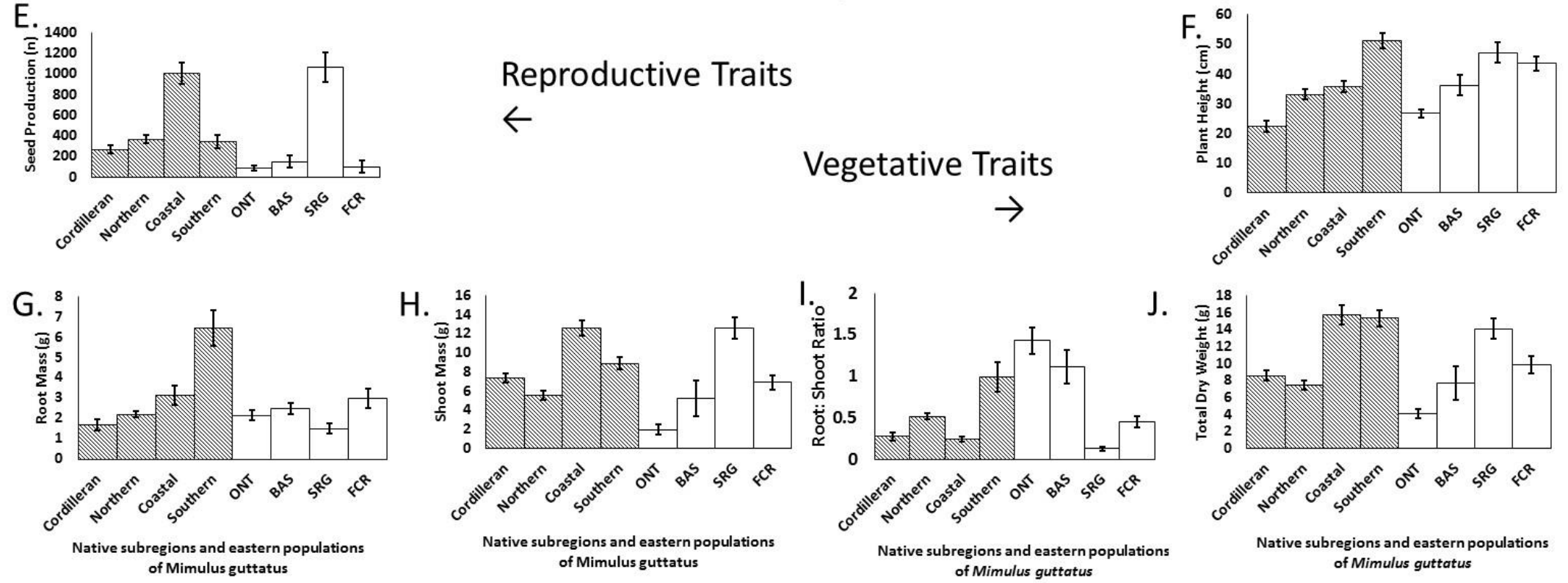

ENA S5. Averages of measures of fitness / competitive ability traits. Reproductive traits: A. Number of days till first flower, B. Width of first corolla, C. Percent of pollen that is viable, D. Total number of flowers produced, E. Number of seeds from first three flowers. Vegetative traits: F.

Plant height, G. Root dry mass, H. Shoot dry mass, I. Root:shoot ratio, J. Total dry biomass for Mimulus guttatus populations between eastern

North American populations (in white) and native subregions (patterned). Error bars represent \pm 1 standard error. Non-transformed data displayed. 
